\title{
INFORMATION SYSTEMS OFFSHORE OUTSOURCING: MANAGERIAL CONCLUSIONS FROM ACADEMIC RESEARCH
}

\author{
Reyes Gonzalez, Juan Llopis, Jose Gasco.
}

\begin{abstract}
In the light of the growing interest raised by Information Systems Offshore Outsourcing both in the managerial world and in the academic arena, the present work carries out a revision of the research in this area.

We have analysed 89 research articles on this topic published in 17 prestigious journals. The analysis deals with aspects such as research methodologies, level of analysis in the studies, data perspective, economic theories used or location of vendors and clients of these services; and it additionally identifies the most frequent topics in this field as well as the most prolific authors and countries.

Although other reviews about the research in this area have been published, the present paper achieves a greater level of detail than previous works. The review of the literature in the area could have interesting implications not only for academics but also for business practice.
\end{abstract}

Keywords: Information Systems, Information Technology, Offshore Outsourcing, research review.

R. González (Corresponding author). Department of Business Organization. University of Alicante. Campus Sant Vicent del Raspeig, s/n. CP: 03690. Alicante. SPAIN.

email: mr.gonzalez@ua.es

J. Llopis. Department of Business Organization. University of Alicante. SPAIN. email: juan.1lopis@ua.es

J. Gasco. Department of Business Organization. University of Alicante. SPAIN. email: j1.gasco@ua.es 


\section{INFORMATION SYSTEMS OFFSHORE OUTSOURCING: MANAGERIAL CONCLUSIONS FROM ACADEMIC RESEARCH}

\section{INTRODUCTION}

Offshore Outsourcing means outsourcing the work associated with Information Technologies (ITs) to a provider based on a country other than that of the client. According to Rottman and Lacity (2008), Offshore Outsourcing is not the same as 'offshoring,' since the latter occurs when an organization moves its activity from one location to another in a different continent. Nevertheless, following the example of previous works written by other authors (Hirschheim 2006; Holmström Olsson et al. 2008; Kelly and Noonan 2008), both terms will be used indifferently and interchangeably throughout this paper.

IS Offshore Outsourcing raises problems similar to those associated with outsourcing inside the same country; it shares the same motivations or reasons which make it attractive and similar risks or potential problems (Cantarello et al. 2011). However, the geographical as well as cultural distance which often exists between clients and providers of these services leads to the emergence of several risks which are specific to Offshore Outsourcing, such as those derived from having to battle with various time zones, different legislations or additional security and privacy problems. For this reason, an enterprise will only decide to venture into this new business area if it has additional incentives, such as the chance to explore foreign markets, to streamline systems development or to achieve a substantial cost reduction (Gonzalez, Gasco and Llopis 2006a; Munoz and Welsh 2006).

In addition to experiencing a considerable growth in the business world, offshore outsourcing has also become one of the most controversial phenomena at the IS field in the academic context during the last few years, as shown by the fact that a considerable number of journals have dedicated their editorials to this topic (see, for example, Kauffman, Clemons and Dewan 2005; King and Torkzadeh 2008; Oshri and Kotlarsky 2008; Patterson 2006; Weber 2004).

In our opinion, this growing interest in the field of offshore outsourcing justifies the decision to make an appraisal of the research carried out so far in this area -which "represents a challenge for the discipline of IS" according to Hirschheim (2006). The present article tries to cope with this challenge, which is also seen as a need, exploring and summarizing the main features of the research devoted to IS Offshore Outsourcing. Our study follows an increasingly widespread tendency interest in the area of IS that has become evident in recent years (Gallivan and Benbunan-Fich 2007). This paper has as its aim to perform an analysis of the research on IS Offshore Outsourcing, answering questions such as: Which research methodologies are used? What level of analysis is reached in these studies? Which data perspective has been followed? Upon which theories are papers based? Where are the clients and providers of outsourced services located? Which topics are treated the most often? Which authors and countries have made the greatest contribution to this area? In fact, questions similar to these have already been posed in previous works (Claver, Gonzalez and Llopis 2000; Gonzalez, Gasco and Llopis 2006a) with a similar objective, that is, to improve our knowledge about this thriving field of study. Hopefully, this paper will offer useful suggestions to those researchers who want to deepen their knowledge of Offshore Outsourcing, but also could have interesting implications for business practice.

\section{METHODOLOGY AND DATA COLLECTION}

The main focus will be placed on the study of articles published in journals of acknowledged prestige in the area of IS, leaving aside other important publication sources, such as books or papers presented at conferences. The main reason for this decision lies in our strong belief that both practitioners and academicians most commonly use journals both to acquire information and to disseminate news. Whereas articles currently represent the most outstanding work in research, other formats, such as books, are confined to gathering and spreading the already established knowledge. As for conferences, it is usual for most valuable papers to end up being published in journals; in fact, the conference represents a step prior to the definitive publication. Finally, it is worth highlighting that popular press -Newsweek, Time- and commercial press -Wired, Infoworld- have been deliberately excluded from our study, a 
decision that other authors had previously adopted in their works as well (Urbaczewski, Jessup and Wheeler 2002).

Table 1 shows the journals which contain the articles on IS Offshore Outsourcing analyzed in the present paper. The journals selected are divided into two groups, namely: IS publications or generalist ones -specialized in Management and Business. After all, as some authors have highlighted before us (Katerattanakul et al. 2005; Nord and Nord 1995), IS researchers also publish in journals devoted to related fields (Yu and Ko 2012). All these journals are listed on the ABI database and, with the exception of Information and Organization, appear on the 2010 lists of SSCI or SCI. It becomes evident that different authors have identified such journals as prestigious publications in the field of IS. By way of example, a comparison has been drawn between the rankings by Dibbern et al. (2004), Katerattanakul et al. (2005), Lowry, Romans and Curtis (2004), Peffers and Ya (2003) and Willcocks, Whitley and Avgerou (2008). The presence of the journal Information and Organization, despite being the only one which does not appear on the SSCI or SCI lists for 2010, is justified by the prestige that most of the aforementioned authors assign to it in terms of IS work publication. As for $C A C M$, it stands out above all for its professional character, and numerous authors are actually dubious about whether it is a professional or an academic publication. However, the paper by Peffers and Ya (2003) concluded that nearly forty per cent of the researchers regard $C A C M$ as an IS research journal. INSERT TABLE 1

Our search through the ABI database ${ }^{1}$ had as its target the articles of those journals included in Table 1 which might contain the terms Offshore Outsourcing, Offshore Sourcing, Offshoring, Offshore Software Development, Global Outsourcing, Global Sourcing or International Outsourcing either in their abstracts or in their keywords or full texts, without specifying the search date. This task was completed with a manual search that focused especially on tracking the reference works in already selected articles and also on searching the manual indices of the selected journals.

A total of 121 articles resulted from the initial search. However, some of them were finally not considered, namely: an article that was a teaching case (Ranganathan, Krishnan and Glickman 2007), six editorials in various journals, eighteen articles which could not be classified as research works because they were opinion columns -all of them published in the journals CACM and ISM- and seven works which, despite dealing with outsourcing or internationalization, did not really fit into the area of offshore outsourcing (such as Fisher, Hirschheim and Jacobs (2008) or Rouse and Baba (2006)). This left us with 89 articles apt for the analysis which went through a complete and exhaustive reading.

\section{RESULTS AND DISCUSSION}

\section{Roadmap}

The next step in our study will be the analysis of the articles on IS Offshore Outsourcing following the scheme illustrated in Figure 1. The explanation for each step in the scheme will be provided later on. INSERT FIGURE 1

\section{Period and journals analyzed}

\section{INSERT FIGURE 2}

The evidence found in the articles reviewed (see Figure 2) reveals that the research on offshore outsourcing started to develop in the early 1990s, although few articles (only 6) were published until 2000. The two pioneering articles examined in our study are the ones written by Ravichandran and Ahmed (1993) "Offshore Systems Development" and Nidomolu and Goodman (1993) "Computing in India: an Asian Elephant learning to dance". Although they were published in the same year, these two papers reflect different perspectives. The former focuses on the advantages and disadvantages of this new form of IT outsourcing, on the possible telematic technologies -emerging in those years- that would eventually make this tendency feasible, and on the ways to orient the decision-making process within this practice; it all from the standpoint of a potential client of such services. Instead, the latter

\footnotetext{
${ }^{1}$ This database, widely accepted in Economics and Business Management, has served as a reference for other previous works which sought similar goals (Hwang \& Thorn, 1999; Mahmood, Hall \& Swanberg, 2001).
} 
seeks to spread the potential that scholars had already started to see in India as the par excellence provider of IT offshore services at the time. Although the perspectives are truly different (that of the client as opposed to that of the provider) the objective remains the same: explaining this business practice in an illustrative, mainly descriptive and informative way that can encourage managers to consider it when the time comes to design their IT and systems strategies.

The number of articles which dealt with this topic between 2002 and 2005 was relatively low too, though it increased during the last period examined (years 2006 to 2010). More precisely, 69 out of 89 articles studied (77.5\%) appeared in the last period, which shows that they treat highly topical issues, at least from the point of view of research on this area.

INSERT TABLE 2

Table 2 presents the journals which have published the most articles about issues related to offshore outsourcing. CACM is the most prolific journal in this respect, with 16 articles, followed by ISM, MISQ and JIT (with 12, 11 and 10 articles, respectively). Not surprisingly, most of the works (80, or $89.9 \%)$ were published in journals classified as IS publications and only $9(10.1 \%)$ in generalist journals.

\section{Research methodologies}

The basis for the analysis of the method applied was found in the work carried out by Alavi and Carlson (1992) to classify theoretical studies, and that of Van Horn (1973), focused on classifying empirical studies. The theoretical studies can come under the labels conceptual, illustrative and applied concepts and are mainly based on ideas, structures and speculations rather than on the systematic and direct observation of reality. Although this type of articles sometimes include observations or empirical data, these play a secondary support role. In other words, the focus is rather on ideas than on data or observations (Gonzalez, Gasco and Llopis 2006a). Conceptual studies describe structures, models or theories, providing explanations or reasons. Instead, Illustrative studies basically try to guide the practice, offer recommendations for action, and explain stages to be fulfilled under certain circumstances. They focus on the 'what' and the 'how', rather than on the 'why'. Finally, Applied concepts studies represent a mixture of the two previous types, their emphasis lying on conceptual as well as explanatory elements.

Regarding empirical studies, although the aforementioned classifications divided them into case studies, field studies, field experiments and laboratory experiments, other forms of research have emerged from the articles examined. This led us to classify the articles as: case studies, field studies, case and field studies and other empirical methods. Case studies are becoming increasingly widespread across the IS area. They basically analyze a phenomenon in its natural environment, obtaining data about it through different means: direct observation, interviews, document analysis, etc., and can be based on the study of one or more cases. The problem with this basically qualitative data collection method lies in the fact that, because it tends to focus on the analysis of a single case or a few cases at the most, generalizing the results obtained becomes quite difficult (Eisenhardt 1989). In field studies, several organizations are examined with respect to one or several variables using an experimental design but without any experimental control. In other words, researchers collect information about uncontrolled situations without altering the operations of their study object. This characteristic is shared with the case study. However, the field study -unlike the case study-applies quantitative methods to analyze the information obtained, which usually comes from interviews. This has a drawback: although gains are achieved in terms of result generalization, the information loses depth and richness. A good way to overcome these inconveniences and enhance the advantages provided by these two methods is to use them jointly through a triangulation of their results (Hamilton and Ives 1982).

INSERT TABLE 3

Table 3 shows how empirical articles prevail (64\%) over theoretical ones (36\%) in the offshore outsourcing literature. However, it is also worth highlighting that only 6 articles appeared during the first period under analysis -most of them theoretical- and the same as in the period comprised between 2001 and 2005, the difference between empirical papers (5 works) and theoretical ones (9 works) decreased. This clearly demonstrates that, as this research field has become more mature, 
scholars have increasingly focused on the direct observation of reality, leaving behind the merely theoretical perspective which had led them to speculate with reality at first.

INSERT TABLE 4

Whereas Table 3 shows which research methods have been used the most often, Table 4 offers a classification of the articles analyzed according to the research method which prevails in them. The highest frequency of use corresponds to case studies ( 28 articles). That is not the case in the field of IS outsourcing in general, where the number of field studies exceeds that of case studies - Dibbern, Winkler and Heinzl (2008) or Lee et al. (2006) are some of the most outstanding case studies on offshore. The second position is occupied by a theoretical method, that is, illustrative studies (24 works, e.g. Seshagiri (1999) or Shao and David (2007)), followed by field studies (17 articles, among them Gopal et al. (2003) or Mao, Lee and Deng (2008)). Finally, 7 theoretical works were found to fit into the category of applied concepts (e.g. Qu and Brocklehurst (2003) or Cha, Pingry and Thatcher (2008)).

The category of 'other empirical methods' includes 10 papers: two which are Delphi studies (such as Iacovou and Nakatsu (2008)), two based on the Analysis of Conversations (Ten-Have 1999) or Conversation Analysis (Avison and Banks (2008) and Sayeed (2008)), another four which present an Analysis of Databases (like Gefen and Carmel 2008), a Laboratory Experiment (Keil, Im and Mähring 2007) and a Literature Review (Heart and Kishore 2009).

As final results, the search identified two papers that combine the field study and case study formats (Agerfalk and Fitzgerald 2008; Leonardi and Bailey 2008) along with a basically conceptual theoretical one (Dutta and Roy 2005).

\section{Level of Analysis, study perspective and theoretical perspective}

\section{FIGURE 3}

Figure 3 shows the level from which the study is performed. $41 \%$ of the articles take as their object of analysis the company or organization as a whole (e.g. Levina and Su 2008), but a considerable number of them mainly examine offshore projects ( 27 articles -i.e. $30 \%-$ among which is the paper by Gopal and Sivaramakrishnan 2008). Numerous works (15) adopt a much broader macroeconomic perspective; they treat the effects caused by offshore on a global scale (Carmel and Abbott 2007) or in a specific country (Joshi and Mudigonda 2008). A group of 6 works focus on the consequences derived from the relationship between outsourcing and the individuals, regardless of whether they are clients or providers of these services (D'Mello and Sahay 2007). Only four papers refer exclusively to the actual offshore outsourcing decision (Ramarapu, Parzinger and Lado 1997) and, finally, one paper looks at offshore both from the standpoint of the organization and from that of the individual (Tambe and Hitt 2010).

\section{INSERT FIGURE 4}

The perspective which served as the basis to carry out the studies shows if the authors were interested mainly or exclusively in the client of offshore outsourcing services, if they essentially paid attention to the provider, or if a balance existed between both perspectives (the client-based approach and the provider-based one). In fact, this is interesting because the outsourcing area had reflected a predominance of the client's perspective until very recently with hardly any papers providing information, experiences and opinions taken from the providers of these services (Yadav and Gupta 2008). However, it becomes evident after examining the papers that, although the vendor's perspective is the one adopted in the least works (24 articles, 27.0\%, e.g. D'Mello and Sahay, (2007) or Rajkumar and Mani (2001)), the distance with the number of articles which adopt the client's perspective (39, i.e. 43.8\%, among them Sakthivel (2007) or Shao and David (2007)) is not so great. Even more interestingly, there is a high number of articles (26, 29.2\%, such as Avison and Banks (2008) or Chua and Pan (2008)) which belong to the group of papers where both standpoints are adopted.

INSERT FIGURE 5

Surprisingly, a vast majority of the articles on offshore outsourcing $(64,71.9 \%)$ do not use the framework of any specific economic theory to structure their contents, and only 25 (the remaining $28.1 \%$ ) use theory to a certain extent (see Figure 5). Among the latter stand out eight papers which use the Transaction Costs theory (such as Qu and Brocklehurst (2003)), five which are based on the Agency theory (like Gefen and Carmel (2008)), four which apply the Knowledge Management theory 
(e.g. Dibbern, Winkler and Heinzl (2008)), three which develop the Resource-based theory (like Ang and Inkpen (2008)) and, finally, two which resort to the Organizational Learning theory (see Cha, Pingry and Thatcher 2008). Some theories (10) are present in only one article; it is the case of the Signaling Theory (Gao, Gopal and Agarwal 2010), the Organizational Behavior theory (Lacity, Iyer and Rudramuniyaiah 2008), Giddens' Theory on Globalization (Kelly and Noonan 2008), Hofstede's Theory (Winkler, Dibbern and Heinzl 2008), the Organizational Culture Theory (Keil, Im and Mähring 2007), the Practice Theory (Levina and Vaast 2008), the Psychological Contract Theory (Agerfalk and Fitzgerald 2008), the Social Capital Theory (Rottman 2008), the Relational Exchange Theory (Holmström Olsson et al. 2008) and the Innovation Theory (Koong, Liu and Wang 2007).

\section{Location of Clients and Providers}

Figure 6 lists the countries where clients are based in the articles under examination. It seems clear that a majority of papers $(51 ; 57.3 \%)$ fail to specify the location of clients of offshore outsourcing services, but there are 38 articles (42.7\%) which do specify the country where the recipients of the outsourced services find themselves. Without a doubt, United States is the country that appears the most often as a client of global outsourcing services in the studies. In fact, it is the only client in 21 articles and appears as the client together with other countries such as Mexico, Switzerland, the United Kingdom, Thailand or the Netherlands in five more papers. In second place, the United Kingdom appears as the country most commonly analyzed as the recipient of offshore services. Clients stayed exclusively in that country in two cases, and in another five, they were not only in the United Kingdom but also in other locations, e.g. Japan, Singapore, Thailand, the United States or the Netherlands. The clients found themselves in Germany on three occasions and other countries whose clients were the object of analysis included Ireland, Switzerland, Japan and Spain.

INSERT FIGURE 6

Figure 7 explains the other end of the spectrum, that is to say, the countries where the providers of the outsourced offshore services find themselves. 43 of the articles examined (48.3\%) indicate no destination (provider) of Offshore services, but India has undoubtedly become the key country inside this group. It appears as the only provider of these services in 36 articles (40.4\%) and acts as the provider together with other countries or regions (e.g. Russia, Eastern Europe, Malaysia, Ireland, Colombia or China) in five more cases. A growing interest has also been raised by the study of China as an offshore power, either on its own as it happens in two articles or along with providers from Japan or India. Finally, it is worth mentioning that one paper studies the Ukraine as the provider of these offshore services too.

INSERT FIGURE 7

\section{Topics}

INSERT TABLE 5

Table 5 provides a detailed breakdown of the topics treated in the articles under study, showing their appearances by periods of time, the number of articles that cover each topic, and the percentage over the total of topics covered. This classification of topics is based on the paper by King and Torkzadeh (2008), from which were adapted the names of ten of the thirteen topics identified in our study. Nevertheless, Table 5 incorporates three new topics (Intercultural Issues, Offshore Typology and Impact on the Staff) which, despite having appeared quite often in the articles examined, did not form part of the proposal made in the aforementioned study. The identification of the topic for each article required not only considering its title and keywords but also reading the article thoroughly in order to be able to classify it as accurately as possible. A number of articles do not deal with a single topic; they can sometimes cover two or even three topics. That explains why the total sum of topics in Table 5 does not equal 83, but 127 .

Outsourcing success factors (Barnir 2012) emerges as the most frequent topic (treated in 25 articles, or $19.7 \%$ of the total), which is in keeping with the results obtained by King and Torkzadeh (2008). This group includes the papers where the authors try to give advice on what to do to ensure that the contract is successful, very often from both the client's and the provider's point of view (Rottman and Lacity 2006) and, on other occasions, only from the client's standpoint (King 2007). The key to practices which can help to make offshoring more successful lies in the proper management of agreements 
between clients and providers. Furthermore, IS professionals must take into consideration some pieces of knowledge required to succeed in the area of offshore outsourcing, namely: negotiation techniques, legislation on contracts, the management of change, and the development of 'soft' knowledge related to having partners and generating trust between client and provider. Of course, a higher level of awareness about the different national cultures becomes vital as well. Among the group of papers which describe success factors also stand out those dealing with the role of trust in outsourcing contracts (Sabherwal 1999) as the most effective way to minimize both the risks and the anxiety that are inherent to offshore outsourcing (Kelly and Noonan 2008). In this respect, it is necessary to balance trust with some well-structured controls previously established in the contract; too much trust and too little control -or, alternatively, too much control and too little trust-inevitably leads to worse Offshore Outsourcing results.

The topic of Risk factors is the second in importance, being studied in seventeen articles (Elango and Chen 2012). These papers revolve around the analysis of risks and propose the following generic risk typology: financial, technical, managerial, behavioral and legal (Kliem 2004). Moreover, some mechanisms for the control and prevention of these risks are suggested (Sakthivel 2007).

Knowledge Management and Vendor-Client Relationships are the third most frequent topics. Indeed, some of the most complicated questions in an offshore outsourcing relationship are the following: How do we transfer the knowledge grasped in IS work practices? How can the organization learn when its reference lies in the development work of a project that another organization is carrying out hundreds or thousands of kilometers away? What is the way to alleviate the adverse effects of work dispersion? And how can we develop learning routines that are apt for transfers from provider to client and vice versa? (Chua and Pan 2008; Ramasubbu et al. 2008). Many firms fear the possibility of decapitalization of their organizational knowledge during the transfer of key processes to the provider. Similarly, providers are afraid that they might not totally understand their client's way of working, which could ultimately result in a bad workflow between both parties (Berbegal-Mirabent, Sabaté and Cañabate 2012; Kao, Wu and Su 2011; Lee and Huan 2012; Park and Rhee 2012; Tuan 2012; Vlaar, Van Fenema and Tiwari 2008).

As for Vendor-client relationship, it is the main concern in several papers that reflect the difficulties associated both with coordination and with the differences in terms of status between work teams belonging to various countries and cultures (Metiu 2006; Mirani 2007). These difficulties are so serious that some firms have to hire an intermediary who acts as a bridge-offshore middlemanbetween onshore and offshore organizations (Mahnke, Wareham and Bjorn-Andersen 2008), helping to soften cultural and cognitive differences during the preparation and pre-contractual negotiation and even in the post-contractual stage.

Project Management topic is covered by twelve articles. The management of international projects -as offshore outsourcing projects are- requires a certain ambivalence between rigor and flexibility, in other words, a dynamic strategy which combines familiarity with the IT structure and agility in project management (Lee, Delone and Espinosa 2006). The work of global software development teams would most probably turn into chaos without rigor and discipline. A detailed, properly-coded documentation along with explicit knowledge becomes critical in a global context because communication can be problematic sometimes and tacit knowledge is hard to share too. Formal communication is important as well, since informal communication often turns out to be less effective than it should due to cultural differences, language barriers and organizational borders. The determination of ways to build inter-organizational teams and the creation of authority and responsibility structures are other issues covered inside this topic (Agerfalk and Fitzgerald 2008), where we have equally included two papers about contracts (Gopal and Sivaramakrishnan 2008, Gopal et al. 2003), their relationship with the characteristics of offshore projects and the results achieved with them. The characteristics of vendors, of clients, and of the actual project, such as uncertainty, project size and scarcity of resources, explain the choice of each project. Likewise, the type of contract, the duration of the project and the size of the team can impact on the benefits derived from this type of initiatives.

Judging by the number of studies that deal with it, Impact of Offshore on the Staff is another relatively important topic (Appelbaum, Roy and Gilliland 2011). This topic includes, on the one hand, the way in which offshore outsourcing affects the IS staff of firms and of outsourcing countries in general, since one of the problems that offshore has to face from a macroeconomic point of view is the loss of 
IS jobs as a result of the strong competition and the 'downward' pressure in the salaries offered by foreign providers (Panko 2008; Pfannenstein and Tsai 2004; Shao and David 2007). On the other hand, it refers to the impact caused by these services on the staff of the provider that delivers these services, which materializes not only in a high turnover rate and a lack of commitment to the firm for which these employees work (Lacity, Iyer and Rudramuniyaiah 2008) but also in a high degree of mobility, not only geographical, but even social and existential (D'Mello and Sahay 2007). The development of offshore outsourcing in countries like India has forced many workers in the IT sector to move from their places of origin toward the software development centers located in large cities such as Bangalore or Hyderabad. This has led to a dispersion of workers, who need to strengthen the bonds with their firm and with their workmates; hence the importance of investing in socialization policies for this type of workers.

The next topic in order of importance is Intercultural Issues (studied by nine articles). Cultural differences hinder communication (Avison and Banks 2008), may cause conflicts, and are most likely to affect the possibilities of success in offshore relationships (Winkler, Dibbern and Heinzl 2008). For all these reasons, cultural differences became the central issue in a considerable number of research works (Keil, Im and Mähring 2007; Nicholson and Sahay 2001).

Offshore Typology receives the attention of nine articles. Under this topic are comprised the works which treat the different typologies of outsourced services, namely: opensource, that is, the development of open source software within a global community (Agerfalk and Fitzgerald 2008) nearshore outsourcing, which would represent the most conservative version of offshore because the delivery of the services outsourced comes from a country that is not very far from the client (Carmel and Abbott 2007); offshore with a mediator or mediated offshore model, where a small provider firm offers its services to a larger IT firm that in turn acts as an interface with the onshore clients (Jarvenpaa and Mao 2008); two-stage offshoring, which takes place when the client looks for a provider that is normally close (nearshore) and that, in turn, looks for another cheaper, more distant provider (offshore) (Holmström Olsson et al. 2008) and multisourcing, where a client looks for several providers of offshore services (Levina and $\mathrm{Su} 2008$ ).

Eight articles focus on the geographical location where offshore services develop. Location is not only one more factor but the key issue in these papers. Six of them analyze India, focusing on the advantages, drawbacks and reasons why this country has become a power in IT outsourcing services (e.g. Joshi and Mudigonda 2008; Nidomolu and Goodman 1993). Other articles propose different, alternative locations and present the factors due to which they can also become important providers of these services; it is the case of China (Qu and Brocklehurst 2003) or the Ukraine (Zatolyuk and Allgood 2004). Among the possible factors which might justify the choice of a country as the destination of offshore projects stand out cost advantages -related to taxes- set-up costs and costs associated with travel and communications; advantages related to human resources, including their knowledge and experience in IT, knowledge of languages, general training, cultural adaptability, and availability of the staff in terms of quantity, quality and mobility (Peña-Vinces, Cepeda-Carrión and Chin 2012). Inhibiting factors include problems associated with political instability, problems with exchange rates, anti-western feelings, protection of intellectual property rights and computer legislation in general. In contrast, government incentives, the support of other institutions such as teaching centers or business associations and the offer of service providers appear as facilitating factors for the choice of a country as an offshore destination.

Four papers focus on the Decision-Making Process (Van Riel et al 2011) in offshore outsourcing (Like Ramarapu, Parzinger and Lado 1997); another two deal with the Economic Value of offshore outsourcing (i.e. Cha, Pingry and Thatcher 2008), and there are also two articles which cover the "24hour Knowledge Factory" paradigm (like Gupta 2009), highlighting the idea that the software projects which are developed by global teams can be functioning 24 hours a day, at least in theory. This is so because, when the working day finishes in some countries, it starts in others, which speeds up the

\footnotetext{
${ }^{2}$ There is a vast area of literature on the topic of open source software development, but this paper reveals an ongoing shift from OSS as a community of individual developers to OSS as a community of commercial organizations, primarily small and medium-sized enterprises, working as a symbiotic ecosystem based on a spirit of co-operation.
} 
development of projects. Finally, there is one paper where the vast proliferation of offshore services makes its authors wonder whether "the world is flat" (Gefen and Carmel 2008).

Table 5 shows the evolution in the volume of articles published at different points in time. It becomes evident that the interest in all topics has increased. In fact, many topics are new, insofar as scholars only started studying them in 2006. It is the case of client-provider relationships; typology of offshore services; economic value; the "24- hour Knowledge Factory" and the proposition about whether "the world is flat." The 'older' topics -which had already appeared in articles since before 2001-are: offshore outsourcing success factors; geographical location of services; risk factors; and decisionmaking. Then, Table 6 classifies the papers by topic.

INSERT TABLE 6

\section{Authors and Countries}

INSERT TABLE 7

Table 7 lists the authors who have published the most articles among those examined here, mentioning their country of origin as well. Our paper follows here the orientation of previous research reviews, which listed the most prolific authors in their respective areas, along with their nationality (Suomi 1996; Claver, Gonzalez and Llopis 2000). It is also worth highlighting that the group of authors in table 7 may not include those who, despite having made a significant contribution to the study of offshore outsourcing, did not publish in the journals analyzed here, though they probably did so in other media, such as books, conference papers or other journals. For this reason, the aforementioned table should not be seen strictly as a ranking, even though it provides a rather accurate picture of the authors who have made a remarkable contribution in this area. On the other hand, it is noticeable that most authors come from the United States ${ }^{3}$, with a variety of other countries too.

INSERT TABLE 8

Going into more detail, the nationality of the authors who publish more articles about this topic is specified in Table 8, which lists the countries that have contributed to a greater extent to IS outsourcing research. This table was elaborated taking each country from the nationality of each author who signs an article, the nationality being that of the institution (mainly the university) where the author was working at the moment in which a specific article was published. The $\mathrm{N}$ value is the number of times that a researcher from one country publishes an article. Therefore, $\mathrm{N}$ tells us how prolific a country is, either in articles or in researchers - or in both. There is a visible predominance of the United States $(\mathrm{N}=116)$, with a great distance over the other countries, followed by India $(\mathrm{N}=15)$, the United Kingdom and the Netherlands $(\mathrm{N}=11)$. Although the number of articles published in other countries is smaller, it is worth highlighting the joint relevance of Asian countries, including China, Singapore and Korea. The cases of Ireland and Germany also deserve a special mention in the European context because these two nations play an outstanding role as providers or clients of offshore outsourcing services.

Finally, a clear tendency to co-authorship seems to exist in Offshore Outsourcing studies, as shown by the fact that only 16 papers are signed by a single author, whereas $73(82.0 \%)$ bear the signature of two or more authors. This preference for co-authorship has actually become consolidated over time, which in turn reflects a certain degree of maturity in the creation and formation of research groups.

\section{CONCLUSIONS AND LIMITATIONS}

The offshore outsourcing research dates back to the early 1990s but it has experienced a spectacular growth during the last few years. Among the eighteen years analyzed, the last ones concentrate the highest number of articles published on this topic. This greater interest from the academic point of view parallels the increase in the hiring of these services worldwide.

As could be expected, the largest proportion of articles examined appear in IS journals, among which CACM has the highest number of articles published on the topic, followed by ISM, MISQ, JIT, I\&M and IM\&DS. Generalist publications also contain some articles dedicated to offshore outsourcing, though much less often. DS belong to this group. The novelty of this research area encourages new

\footnotetext{
${ }^{3}$ This does not necessarily mean that they are nationals of this country; it only means that they are developing their research tasks there.
} 
researchers to join it. Furthermore, an interesting outlet for publications in this area can be found in the most generalist journals, where these works become even more innovative.

The articles examined are mostly empirical, case analysis standing out as the most frequent research method, both separately and in combination with field study. Regarding theoretical works, the illustrative ones, that is, those which try to guide practice from theory, deserve a special mention. Various articles appeared in recent years reveal the implementation of other empirical methods, from the Delphi method to the laboratory experiment, the analysis of conversations, etc. This shows the interest in experimentation that has been arising within the area lately.

Most studies find their study object in the organization as a whole, although there are a considerable number of papers where the study object is the project itself. A third group offers a macroeconomic context, explaining the consequences of outsourcing either globally or in a specific country.

Although the articles based on the client's perspective prevail over those which focus on the provider, an increasing number of studies are now using both perspectives at the same time or focusing exclusively on the provider's perspective. This new stance is in keeping with the conclusions drawn from previous papers (Mahnke, Wareham and Bjorn-Andersen 2008).

The studies analyzed do not adopt an economic theory for their justification very often but, when they do use one, the Transaction Costs Theory, the Knowledge Management Theory and the Agency Theory appear as the most popular theoretical frameworks. This lack of theoretical formalization may be due to the 'young age' of this area, but also to the mainly informative nature of these research works, which seem to have as their aim to spread the topic, to encourage experimentation in the area, and to explain its risks both to clients and to providers, and do not assign so much importance to the efforts to set up a more formalized theoretical scheme. It becomes consequently clear that the theoretical foundations of research in this area need to be improved and reinforced so that more rigorous results can be obtained.

Although many of the papers examined fail to specify where the clients or providers of offshore outsourcing are located, the ones which do provide that location clearly show United States and to a lesser extent the United Kingdom and Germany as recipients of these services, and India -and to a lesser extent China- as providers. However, it is worth mentioning that the experience of offshore outsourcing, both as clients and as providers, is already spreading to other countries.

Among the topics most often treated in the research stand out offshore success factors with a growing interest in the management of the knowledge related to this type of relationships during the last few years. Risk Factors, Project management and Vendor-Client Relationship raise a lot of interest too, the choice of topics reflecting the mainly informative nature of the publications once again.

Topic analysis shows that, despite the diversity of study areas, no controversies and conflicting research lines exist. All articles converge on the importance to establish coordination, communication, control and training policies which can strengthen the bonds between clients and providers of the services delivered and overcome the potential cultural differences between client and provider countries.

The United States is obviously the most prolific country in this area, which comes as no surprise considering the prevalence of Anglo-Saxon countries in the IS context. Asian countries and some European ones are also publishing in this field, which is probably a sign that the regions involved in these practices -either as clients or as providers-are beginning to pay attention to the research work focused on them. Once more, this result shows the prevalence of the United States as the most prolific country in the research on the area of IS as a whole, and on IS Outsourcing in particular (Suomi 1993, Gonzalez, Gascó and Llopis 2006a). It is US universities that have best explained what we know about Offshore Outsourcing at present.

In our opinion, the present paper makes a significant contribution to spread the knowledge about the area of IS Offshore Outsourcing, although it is also true that other reviews about the research in this area have been published. Among them stands out the pioneering study of Smith, Mitra and Narashiman (1996), who proposed a framework to organize the issues related to offshore outsourcing. However, our paper updates the review of the research and includes many more studies, as well as the works of Dibbern et al. (2004), Lacity et al. (2010) and Gonzalez, Gasco and Llopis (2006a), which refer to the most general area of IS Outsourcing. By limiting the study to Offshore Outsourcing, the present paper achieves a greater level of detail than these previous works. 
The paper also has interesting implications for practitioners, those running a firm or entrepreneurs trying to open new ventures. On the one side, it explains widely the topic of Offshore Outsourcing on the computer area, indicating countries that could be attractive destinations for future businesses. On the other side, the most important topics in international relations at the IS department could be extrapolated to other functions of the firms. So issues like "success factors", risk management" or "knowledge management" should be taken into account in any international project. Having in mind that many new businesses are based on ITs it is not difficult to justify the importance of this paper for practitioners.

Regarding limitations, it is necessary to emphasize those deriving from the fact that the study of the offshore outsourcing research has been constrained to articles published in certain journals, leaving aside books and conference papers. The decision to examine the research published only in some prestigious journals was based on our desire to study articles which had gone through a rigorous review and selection process and presented a scientific methodology, even though this could have the inconvenience of showing results from a narrower range of journals. All things considered, the authors of this paper think that "perhaps not all the existing ones are mentioned, but all the ones that are mentioned deserve to be here"; in other words, all the research analyzed in this paper is relevant enough and has sufficient quality to provide a faithful description of IS Offshore Outsourcing. Hopefully, this research work will help to improve the knowledge about this area and encourage other scholars to continue -or start- working in this thriving field of research.

\section{REFERENCES}

Agerfalk, P.J. \& Fitzgerald, B. (2008). Outsourcing to an unknown workforce: exploring Opensourcing as a global sourcing strategy. MIS Quarterly, 32(2), 385-409.

Aggarwal, A. (2008). Emerging Markets: India's Role in The Globalization of IT. Communications of the ACM, 51(7), 17-19.

Alavi, M. \& Carlson, P. (1992). A Review of MIS Research and Disciplinary Development. Journal of Management Information Systems, 8(4), 45-62.

Ang, S. \& Inkpen, A.C. (2008). Cultural Intelligence and Offshore Outsourcing Success: a Framework of FirmLevel Intercultural Capability. Decision Sciences, 39(3), 337-358.

Appelbaum, S.H., Roy, M. \& Gilliland, T. (2011). Globalization of performance appraisals: theory and applications. Management Decision, 49(4), 570-585.

Avison, D. \& Banks, P. (2008). Cross-cultural (mis)communication in IS offshoring: understanding through conversation analysis. Journal of Information Technology, 23(4), 249- 268.

Bapna, R., Barua, A., Mani, D. \& Mehra, A. (2010). Cooperation, coordination, and governance in multisourcing: an agenda for analytical and empirical research. Information Systems Research, 21 (4), 785-795. BarNir, A. (2012). Starting technologically innovative ventures: reasons, human capital, and gender. Management Decision, 50(3), 399- 419.

Batra, D. (2009). Modified agile Practices for Outsourced Software Projects. Communications of the ACM, 52(9), 143-148.

Berbegal-Mirabent, J., Sabaté, F. \& Cañabate, A. (2012). Brokering knowledge from universities to the marketplace: The role of knowledge transfer offices. Management Decision, 50(7), 1285- 1307.

Bharadwaj, S.S., Saxena, K.B. \& Halemane, M.D. (2010). Building a successful relationship in business process outsourcing: an exploratory study. European Journal of Information Systems, 19(2), 168-180.

Bharadwaj, S.S. \& Saxena, K.B.C. (2009). Building Winning Relationships in Business Process. Industrial Mangement \& Data Systems, 109(7), 993-1011.

Cantarello, S. \& Nosella, A. (2011). Giorgio Petroni, Karen Venturini External technology sourcing: evidence from design-driven innovation. Management Decision, 49(6), 962 - 983.

Carmel, E. \& Abbott, P. (2007). Why 'Nearshore' means that distance matters. Communications of the ACM, 50(10), 40-46.

Cha, H.S., Pingry, D.E. \& Thatcher, M.E. (2008). Managing the Knowledge Supply Chain: an Organizational Learning Model of Information Technology Offshore Outsourcing. MIS Quarterly, 32(2), 281-306.

Chua, A.L. \& Pan, S.L. (2008). Knowledge transfer and organizational learning in IS offshore sourcing. Omega, 36(2), 267-281.

Claver, E., Gonzalez, R. \& Llopis, J. (2000). An Analysis of Research on Information Systems (1981-1997).

Information \& Management, 37(4), 181-195. 
Conchúir, E.O., Agerfalk, P.J., Olsson, H.H. \& Fitzgerald, B. (2009). Global Software Development: Where are the benefits. Communications of the ACM, 52(8), 127-131.

D’Mello, M. \& Eriksen, T.H. (2010). Software, sports and sheera. Culture and identity processes within a global software organization in India. Information and Organization, 20(2), 81-110.

D’Mello, M. \& Sahay, S. (2007). 'I am kind of a nomad where I have to go places and places'... Understanding mobility, place and identity in Global Software Work from India. Information and Organization, 17(3), 162-192. Dibbern, J., Goles, T., Hirschheim, R. \& Jayatilaka, B. (2004). Information Systems Outsourcing: A Survey and Analysis of the Literature. Database for Advances in Information Systems, 35(4), 6-102.

Dibbern, J., Winkler, J. \& Heinzl, A. (2008). Explaining Variations in Client Extra Costs between Software Projects Offshored to India. MIS Quarterly, 32(2), 333-366.

Donohue, J.M. \& Fox, J.B. (2000). A multi-method evaluation of journals in the decision and management sciences by US academics. OMEGA, 28(1), 17-36.

Dutta, A. \& Roy, R. (2005). Offshore Outsourcing: a dynamic causal model of counteracting forces. Journal of Management Information Systems, 22(2), 15-35.

Eisenhardt, K.M. (1989). Building Theories from Case Study research. Academy of Management Review, 14(4), 532-550.

Elango, B. \& Chen, S. (2012). Learning To Manage Risks In International R\&D Joint Ventures Through Ownership Decisions. Management Decision, 50(8), 1425-1444.

Fisher, J., Hirschheim, R. \& Jacobs, R. (2008). Understanding the outsourcing learning curve: A longitudinal analysis of a large Australian company. Information Systems Frontiers, 10(2), 165-178.

Gallivan, M.J. \& Benbunan-Fich, R. (2007). Analyzing IS research productivity: an inclusive approach to global IS Scholarship. European Journal of Information Systems, 16(1), 36-53.

Gao, G., Gopal, A. \& Agarwal, R. (2010). Contingent Effects of Quality Signaling: evidence from the Indian Offshore IT services Industry. Management Science, 56(6), 1012-1029.

Gefen, D. \& Carmel, E. (2008). Is the world really flat? A look at offshoring at an online programming marketplace. MIS Quarterly, 32(2), 367-384.

Gonzalez, R., Gasco, J. \& Llopis, J. (2006a). Information Systems outsourcing: A literature analysis.

Information \& Management, 43(7), 821-834.

Gonzalez, R., Gasco, J. \& Llopis, J. (2006b). Information Systems Offshore Outsourcing: A Descriptive

Analysis. Industrial Management \& Data Systems, 106(9), 1233-1248.

Gonzalez, R., Gasco, J. \& Llopis, J. (2010). Information Systems Offshore Outsourcing: an exploratory study of motivations and risks in large Spanish firms. Information Systems Management, 27(4), 340-355.

Gopal, A. \& Koka, B.R. (2010). The role of Contracts on quality and returns to quality in Offshore Software Development Outsourcing. Decision Sciences, 41(3), 491-516.

Gopal, A. \& Sivaramakrishnan, K. (2008). On Vendor Preferences for Contract Types in Offshore Software Projects: The Case of Fixed Price vs. Time and Materials Contracts. Information Systems Research, 19(2), 202220.

Gopal, A., Mukhopadhyay, T. \& Krishnan, M.S. (2002). The role of software processes and communication in offshore software development. Communications of the ACM, 45(4), 193-200.

Gopal, A., Sivaramakrishnan, K., Krishnan, M.S. \& Mukhopadhyay, T. (2003). Contracts in Offshore Software Development: an Empirical Analysis. Management Science, 49(12), 1671-1683.

Gupta, A. (2009). Deriving Mutual Benefits form Offshore Outsourcing. Communications of the ACM, 52(6), 122-126.

Gupta, A., Crk, I. \& Bondade, R. (2010). Leveraging temporal and spatial separations with the 24-hour knowledge factory paradigm. Information Systems Frontiers, 13(3), 397-405.

Hahn, E.D., Doh, J.P. \& Bunyaratavej, K. (2009). The Evolution of Risk in Information Systems Offshoring: The Impact of Home Country Risk, Firm Learning, and Competitive Dynamics. MIS Quarterly, 33(3), 597-616. Hamilton, S. \& Ives, B. (1982). MIS Research Strategies. Information \& Management, 5(6), 339-347.

Herath, T. \& Kishore, R. (2009). Offshore Outsourcing: Risks, Challenges, and Potential Solutions. Information Systems Management, 26(4), 312-326.

Hirschheim, R. (2006). "Offshore Outsourcing: Challenge to the Information Systems Discipline”, in Hirschheim, R.; Heinzl, A. \& Dibbern, J. (eds.), Information Systems Outsourcing. Enduring Themes, New Perspectives and Global Challenges, second Edition. Springer. Berlin.

Hirschheim, R. (2009). Offshoring and the New World Order. Communications of the ACM, 52(11), 132-135. Hirschheim, R \& Newman, M. (2010). Houston, we've had a problem... offshoring, IS employment and the IS discipline: perception is not reality. Journal of Information Technology, 25(4), 358-372.

Holmström Olsson, H., Conchúir, E.Ó., Ågerfalk, P.J. \& Fitzgerald, B. (2008). Two-Stage Offshoring: An Investigation of the Irish Bridge. MIS Quarterly, 32(2), 257-279.

Hwang, M.I. \& Thorn, R.G. (1999). The effect of User Engagement on System Success: A meta-analytical Integration of research Findings. Information \& Management, 35(4), 229-236. 
Iacovou, Ch.L. \& Nakatsu, R. (2008). A Risk profile of Offshore-Outsourced development projects. Communications of the ACM, 51(6), 89-94.

Jarvenpaa, S.L. \& Mao, J-Y. (2008). Operational capabilities development in mediated offshore software services models. Journal of Information Technology, 23(1), 3-17.

Joshi, K. \& Mudigonda, S. (2008). An analysis of India's future attractiveness as an offshore destination for IT and IT-enabled services. Journal of Information Technology, 23(4), 215-227.

Kao, S.C., Wu, C.H. \& Su, P.C. (2011). Which mode is better for knowledge creation? Management Decision, 49(6), 1037-1060.

Katerattanakul, P., Razi, M.A., Han, B.T. \& Kam, H-J. (2005). Consistency and Concern on IS Journal Rankings. Journal of Information Technology Theory and Application, 7(2), 1-20.

Kauffman, R.J., Clemons, E.K. \& Dewan, R.M. (2005). Special Section: Information Systems in Competitive Strategies: Offshoring, Risk Management, Strategic Pricing, E-Sourcing, and Standards. Journal of Management Information Systems, 22(2), 7-13.

Keil, M., Im, G.P. \& Mähring, M. (2007). Reporting bad news on software projects: the effects of culturally constituted views of face-saving. Information Systems Journal, 17(1), 59-87.

Kelly, S. \& Noonan, C. (2008). Anxiety and psychological security in offshoring relationships: the role and development of trust as emotional commitment. Journal of Information Technology, 23(4), 232-248.

King, W.R. \& Torkzadeh, G. (2008). Information Systems Offshoring: Research Status and Issues. MIS Quarterly, 32(2), 205-225.

King, W.R. (2006). Offshoring Decision Time is at Hand. Information Systems Management, 23(3), 102-103.

King, W.R. (2007). The IS Organization of the Future: Impacts of Global Sourcing. Information Systems Management, 24(2), 121-127.

King, W.R. (2008). Issues in IS Offshoring. Information Systems Management, 25(3), 287-289.

Kliem, R. (2004). Managing the Risks of Offshore IT Development Projects. Information Systems Management, 21(3), 22-27.

Koong, K.S., Liu, L.C. \& Wang, Y.J. (2007). Taxonomy Development and Assessment of Global Information Technology Outsourcing Decisions. Industrial Management \& Data Systems, 107(3), 397-414.

Kotlarsky, J. \& Oshri, I. (2008). Country Attractiveness for Offshoring and Offshore Outsourcing: additional Considerations. Journal of Information Technology, 23(4), 228-231.

Kotlarsky, J., Oshri, I., Van Hillegersberg, J. \& Kumar, R. (2007). Globally distributed component-based software development: an exploratory study of knowledge management and work division. Journal of Information Technology, 22(2), 161-173.

Krishna, S., Sahay, S. \& Walsham, G. (2004). Managing Cross-Cultural Issues in Global Software Outsourcing. Communications of the ACM, 47(4), 62-66.

Lacity, M.C., Iyer, V.V. \& Rudramuniyaiah, P.S. (2008). Turnover Intentions of Indian Professionals.

Information Systems Frontiers, 10(2), 225-241.

Lacity, M.C., Khan, S., Yan, A. \& Willcocks, L.P. (2010). A Review of the IT Outsourcing empirical Literature and Future Research Directions. Journal of Information Technology, 25 (4), 395-433.

Lee, C.Y. \& Huang, Y.C. (2012). Knowledge stock, ambidextrous learning, and firm performance: Evidence form technologically intensive industries. Management Decision, 50(6), 1096-1116.

Lee, G., Delone, W. \& Espinosa, J.A. (2006). Ambidextrous coping strategies in globally distributed software development projects. Communications of the ACM, 49(10), 35-40.

Lee, O-K., Banerjee, P., Lim, K.H., Kumar, K. et al. (2006). Aligning IT Components to achieve agility in globally distributed systems development. Communications of the ACM, 49(10), 49-54.

Leonardi, P.M. \& Bailey, D.E. (2008). Transformational Technologies and the Creation of New Work Practices: Making Implicit Knowledge Explicit in Task-Based Offshoring. MIS Quarterly, 32(2), 411-436.

Levina, N. \& Su, N. (2008). Global Multisourcing Strategy: The emergence of a Supplier Portfolio in Services Offshoring. Decision Sciences, 39(3), 541-570.

Levina, N. \& Vaast, E. (2008). Innovating or Doing as Told? Status Differences and Overlapping Boundaries in Offshore Collaboration. MIS Quarterly, 32(2), 307-332.

Lowry, P.B., Romans, D. \& Curtis, A. (2004). Global Journal Prestige and Supporting Disciplines: A Scientometric study of Information Systems Journals. Journal of the Association for Information Systems, 5(2), 29-77.

Mahmood, M.A., Hall, L. \& Swanberg, D.L. (2001). Factors affecting information technology usage: a metaanalysis of the empirical literature. Journal of Organizational Computing and Electronic Commerce, 11(2), 107130.

Mahnke, V., Wareham, J. \& Bjorn-Andersen, N. (2008). Offshore middlemen: transnational intermediation in technology sourcing. Journal of Information Technology, 23(1), 18-30.

Mao, J-Y., Lee, J-N. \& Deng, Ch-P. (2008). Vendors' perspectives on trust and control in offshore information systems outsourcing. Information \& Management, 45(7), 482-492.

Metiu, A. (2006). Owning the code: status Closure in Distributed Groups. Organization Science, 17(4), 418-435. 
Mirani, R. (2007). Procedural coordination \& offshored software tasks: Lessons from two case studies. Information \& Management, 44(2), 216-230.

Munoz, J.M. \& Welsh, D.H.B. (2006). Outsourcing in the IT Industry: The case of the Philipines. International Entrepreneurship and Management Journal, 2(1), 111-123.

Nair, K.G.K. \& Prasad, P.N. (2004). Offshore Outsourcing: A SWOT Analysis of a State in India. Information Systems Management, 21(3), 34-40.

Nakatsu, R.T. \& Iacovou, Ch.L. (2009). A comparative study of important risk factors involved in offshore and domestic outsourcing of software development projects: A two-panel Delphi study. Information \& Management, 46(1), 57-68.

Nicholson, A. \& Sahay, S. (2001). Some Political and Cultural Issues in the Globalisation of Software Development: case experience from Britain and India. Information and Organization, 11(1), 25-34.

Nicholson, A. \& Sahay, S. (2004). Embedded Knowledge and Offshore Software Development. Information and Organization, 14(4), 329-365.

Nidumolu, S.R. \& Goodman, S.E. (1993). Computing in India: An Asia elephant learning to dance. Communications of the ACM, 36(6), 15-22.

Nord, J.H. \& Nord, G.D. (1995). MIS Research: Journal Status assessment and Analysis. Information \& Management, 29(1), 29-42.

Oshri, I. \& Kotlarsky, J. (2008). Special Issue on Global Sourcing: IT Services, Knowledge and Social Capital. Journal of Information Technology, 23(1), 1-2.

Oshri, I., Van Fenema, P. \& Kotlarsky, J. (2008). Knowledge transfer in globally distributed teams: the role of transactive memory. Information Systems Journal, 18(6), 1-24.

Palvia, P.C., King, R.C., Xia, W. \& Palvia, S.C.J. (2010). Capability, quality and performance of Offshore IS Vendors: a theoretical framework and empirical investigation. Decision Sciences, 41(2), 231-270.

Panko, R.R. (2008). IT employment prospects: beyond the dotcom bubble. European Journal of Information Systems, 17(3), 182-197.

Park, T. \& Rhee, J. (2012). Antecedents of knowledge competency and performance in Born Globals: the moderating effects of absorptive capacity. Management Decision, 50(8), 1361-1381.

Patterson, D.A. (2006). Offshoring; finally facts vs. folklore, Communications of the ACM, 49(2), 41-42.

Peffers, K. \& Ya, T. (2003). Identifying and evaluating the universe of outlets for Information Systems Research: ranking the journals. Journal of Information Technology Theory and Application, 5(1), 63-84.

Peña-Vinces, J.C., Cepeda-Carrión, G. \& Chin, W.W. (2012). Effect of ITC on the international competitiveness of firms. Management Decision, 50(6), 1045- 1061.

Pfannenstein, L.L. \& Tsai, R.J. (2004). Offshore Outsourcing: Current and Future Effects on American IT Industry. Information Systems Management, 21(4), 72-80.

Qu, Z. \& Brocklehurst, M. (2003). What will it take for China to become a competitive force in offshore outsourcing? An analysis of the role of transaction costs in supplier selection. Journal of Information Technology, 18(1), 53-67.

Rai, A., Maruping, L.M. \& Venkatesh, V. (2009). Offshore Information Systems Project Success: The Role of Social Embeddedness and Cultural Characteristics. MIS Quarterly. 33(3), 617-641.

Rajkumar, T.M. \& Mani, R.V.S. (2001). Offshore software development: The view from Indian suppliers. Information Systems Management, 18(2), 63-73.

Ramarapu, N., Parzinger, M.J. \& Lado, A.A. (1997). Issues in foreign outsourcing: Focus on applications development and support. Information Systems Management, 14(2), 2731.

Ramasubbu, N., Mithas, S., Krishnan, M.S. \& Kemerer, Ch.F. (2008). Work Dispersion, Process-Based Learning, and Offshore Software Development Performance. MIS Quarterly, 32(2), 437-458.

Ramesh, A., Cao, L., Mohan, K. \& Xu, P. (2006). Can distributed software be agile? Communications of the ACM, 49(10), 41-46.

Ranganathan, A., Krishnan, P. \& Glickman, R. (2007). Crafting and executing an offshore IT sourcing strategy: GlobShop's experience. Journal of Information Technology, 22(4), 440-450.

Rao, M.T. (2004). Key Issues for Global IT Sourcing: Country and Individual Factors. Information Systems Management, 21(3), 16-21.

Ravichandran, R. \& Ahmed, N.U. (1993). Offshore systems development. Information \& Management, 24(1), 33-40.

Rottman, J.W. \& Lacity, M.C. (2006). Proven Practices for Effectively Offshoring IT Work. MIT Sloan Management Review, 47(3), 56-63.

Rottman, J.W. \& Lacity, M.C. (2008). A US Client's learning from outsourcing IT work offshore. Information Systems Frontiers, 10(2), 259-275.

Rottman, J.W. (2008). Successful knowledge transfer within offshore supplier networks: a case study exploring social capital in strategic alliances. Journal of Information Technology, 23(1), 31-43.

Rouse, W.B. \& Baba, M.L. (2006). Enterprise Transformation. Communications of the ACM, 49(7), 66-72. 
Sabherwal, R. (1999). The role of Trust in outsourced IS development projects. Communications of the ACM, 42(2), 80-86.

Sakthivel, S. (2007). Managing Risks in Offshore Systems Development. Communications of the ACM, 50(4), 69-75.

Sarker, S., Sarker, S. \& Jana, D. (2010). The impact of the nature of globally distributed work arrangement on work-life conflict and valence: the Indian GSD professionals' perspective. European Journal of Information Systems, 19(2), 209-222.

Sayeed, L. (2008). Managerial Cost Mitigation Tactics in Offshore IT Projects. Industrial Management \& Data Systems, 108(9), 1219-1233.

Seshagiri, N. (1999). The Informatics Policy in India. Information Systems Frontiers, 1(1), 107-116.

Shao, B.B.M. \& David, J.S. (2007). The impact of Offshore Outsourcing on IT workers in developed countries. Communications of the ACM, 50(2), 89-94.

Simon, J.C., Poston, R.S. \& Kettinger, B. (2009). Creating Better Governance of Offshore Services. Information Systems Management, 26(2), 110-122.

Sledgianowski, D., Tafti, M.H.A. \& Kierstead, J. (2008). SME ERP System Sourcing Strategies: A Case Study. Industrial Management \& Data Systems, 108(4), 421-436.

Smith, M.A., Mitra, S. \& Narasimhan, S. (1996). Offshore outsourcing of software development and maintenance: A framework for issues. Information \& Management, 31(3), 165-175.

Suomi, R. (1993). On the Nationality Balance of Authors and References in Selected MIS Journals. Information \& Management, 24(6), 339-347.

Tafti, M.H.A. (2005). Risks Factors Associated with Offshore IT Outsourcing. Industrial Management \& Data Systems, 105(5), 549-560.

Tambe, P.B. \& Hitt, L.M. (2010). How offshoring affects IT workers. Communications of the ACM, 53(10), 6270.

Tanriverdi, H., Konana, P. \& Ge, L. (2007). The Choice of Sourcing Mechanisms for Business Processes.

Information Systems Research, 18(3), 280-299.

Ten-Have, P. (1999). Doing Conversation Analysis - A Practical Guide. Sage, London.

Tuan, L.T. (2012). Behind knowledge transfer. Management Decision, 50(3), 459 - 478.

Urbaczewski, A., Jessup, L.M. \& Wheeler, B. (2002). Electronic Commerce Research: a Taxonomy and Synthesis. Journal of Organizational Computing and Electronic Commerce, 12(4), 263-305.

Van Horn, R.L. (1973). Empirical Studies of Management Information Systems. Database, 5(4-5), 172-180.

Van Riel, A.C.R., Semeijn, J., Hammedi, W. \& Henseler, J. (2011). Technology-based service proposal screening and decision-making effectiveness. Management Decision, 49(5), 762 - 783.

Vlaar, P.W.L., Van Fenema, P.C. \& Tiwari, V. (2008). Cocreating Understanding and Value in Distributed Work: How Members of Onsite and Offshore Vendor Teams Give, Make, Demand, and Break Sense. MIS Quarterly, 32(2), 227-255.

Weber, R. (2004). Editor's comments: Some Implications of the Year-2000 Era, Dot-Com Era, and Offshoring for Information Systems Pedagogy. MIS Quarterly, 28(2), III-XI.

Webster, J. \& Watson, R.T. (2002). Analyzing the past to prepare for the future: Writing a literature review. MIS Quarterly, 26(2), xiii-xxiii.

Westner, M. \& Strahringer, S. (2010). Determinants of success in IS offshoring projects: Results from an empirical study of German companies. Information \& Management, 47(5-6), 291-299.

Whitaker, J. Mithas, S. \& Krishnan, M.S. (2010). Organizational Learning and Capabilities for Onshore and Offshore Business Process Outsourcing. Journal of Management Information Systems, 27(3), 11-42.

Willcocks, L., Whitley, E.A. \& Avgerou, Ch. (2008). The ranking of top IS journals: a perspective from the London School of Economics. European Journal of Information Systems, 17(2), 163-168.

Winkler, J.K., Dibbern, J. \& Heinzl, A. (2008). The impact of cultural differences on offshore outsourcing- Case study results from German-Indian application development projects. Information Systems Frontiers, 10(2), 243 258.

Yadav, V. \& Gupta, R.K. (2008). A Paradigmatic and Methodological Review of Research in Outsourcing. Information Resources Management Journal, 21(1), 27-43.

Yu, H. \& Ko, H.T. (2012). Integrating Kano model with strategic experiential modules in developing ICTenabled services: An empirical study. Management Decision, 50(1), 7-20.

Zatolyuk, S. \& Allgood, B. (2004). Evaluating a Country for Offshore Outsourcing: Software Development Providers in the Ukraine. Information Systems Management, 21(3), 28-33. 
Table 1: Journals analyzed

\begin{tabular}{|c|c|c|c|c|c|c|}
\hline & Journals & $\begin{array}{l}\text { Dibbern et } \\
\text { al. }(2004)\end{array}$ & $\begin{array}{l}\text { Katerattanakul } \\
\text { et al. }(2005)\end{array}$ & $\begin{array}{l}\text { Lowry, Romans \& } \\
\text { Curtis (2004) }\end{array}$ & $\begin{array}{l}\text { Peffers \& } \\
\text { Ya (2003) }\end{array}$ & $\begin{array}{c}\text { Willcocks, Whitley \& } \\
\text { Avgerou (2008) }\end{array}$ \\
\hline \multirow{12}{*}{$\mathscr{\Omega}$} & CACM & $*$ & $*$ & * & - & $*$ \\
\hline & EJIS & $*$ & $*$ & $*$ & $*$ & $*$ \\
\hline & I\&M & $*$ & $*$ & $*$ & $*$ & $*$ \\
\hline & $\mathrm{I} \& \mathrm{O}$ & $*$ & - & $*$ & $*$ & * \\
\hline & IM\&DS & - & - & - & $*$ & - \\
\hline & ISF & - & - & - & $*$ & $*$ \\
\hline & ISJ & $*$ & $*$ & $*$ & $*$ & $*$ \\
\hline & ISM & - & $*$ & - & $*$ & - \\
\hline & ISR & $*$ & $*$ & $*$ & $*$ & $*$ \\
\hline & JIT & $*$ & - & * & $*$ & $*$ \\
\hline & JMIS & $*$ & - & $*$ & $*$ & * \\
\hline & MISQ & $*$ & $*$ & $*$ & $*$ & $*$ \\
\hline \multirow{5}{*}{$\begin{array}{l}\frac{\Omega}{1} \\
\stackrel{1}{1} \\
Z\end{array}$} & DS & $*$ & $*$ & - & $*$ & - \\
\hline & MITSMR & $*$ & $*$ & $*$ & - & $*$ \\
\hline & MS & $*$ & $*$ & $*$ & $*$ & $*$ \\
\hline & OMEGA & - & - & - & $*$ & - \\
\hline & OS & $*$ & $*$ & $*$ & $*$ & $*$ \\
\hline
\end{tabular}

CACM: Communications of the ACM; EJIS: European Journal of Information Systems; I\&M: Information \& Management; I\&O: Information and Organization; IM\&DS: Industrial management \& Data Systems; ISF: Information Systems Frontiers; ISJ: Information Systems Journal; ISM: Information Systems Management; ISR: Information Systems Research; JIT: Journal of Information Technology; JMIS: Journal of Management Information Systems; MISQ: Management Information Systems Quarterly; DS: Decision Sciences MITSMR: MIT Sloan Management Review; MS: Management Science; OMEGA: OMEGA; OS: Organization Science.

Table 2: Number of IS Offshore Outsourcing articles in each journal

\begin{tabular}{|lrr|}
\hline & $\mathrm{N}$ & $\%$ \\
\hline CACM & 16 & 18.0 \\
ISM & 12 & 13.5 \\
MISQ & 11 & 12.4 \\
JIT & 10 & 11.2 \\
I\&M, IM\&DS & 6 & 6.7 \\
ISF & 5 & 5.6 \\
DS, I\&O & 4 & 4.5 \\
EJIS, ISR & 3 & 3.4 \\
ISJ, JMIS, MS & 2 & 2.2 \\
MITSMR, OMEGA, OS & 1 & 1.1 \\
\hline TOTAL & 89 & 100.0 \\
\hline
\end{tabular}

Table 3: Research Methodologies in IS Offshore Outsourcing

\begin{tabular}{|l|r|r|r|r|}
\hline & Until 2000 $(\%)$ & 2001-2005(\%) & 2006-2010 (\%) & \multicolumn{1}{c|}{ TOTAL (\%) } \\
\hline Total Theoretical & $5 ; 5.6$ & $9 ; 10.1$ & $18 ; 20.2$ & $32 ; 36.0$ \\
\hline Conceptual & $0 ; 0.0$ & $1 ; 1.1$ & $0 ; 0.0$ & $1 ; 1.1$ \\
Illustrative & $4 ; 4.5$ & $7 ; 7.9$ & $13 ; 14.6$ & $24 ; 27.0$ \\
Applied concepts & $1 ; 1.1$ & $1 ; 1.1$ & $5 ; 5.6$ & $7 ; 7.9$ \\
\hline Total Empirical & $1 ; 1.1$ & $5 ; 5.6$ & $51 ; 57.3$ & $57 ; 64.0$ \\
\hline Case studies & $1 ; 1.1$ & $2 ; 2.2$ & $25 ; 28.1$ & $28 ; 31.5$ \\
Field studies & $0 ; 0.0$ & $3 ; 3.3$ & $14 ; 15.7$ & $17 ; 19.1$ \\
Case and field studies & $0 ; 0.0$ & $0 ; 0.0$ & $2 ; 2.2$ & $2 ; 2.2$ \\
Other empirical studies & $0 ; 0.0$ & $0 ; 0.0$ & $10 ; 11.2$ & $10 ; 11.2$ \\
\hline TOTAL & $6 ; 6.7$ & $14 ; 15.7$ & $69 ; 77.5$ & $89 ; 100.0$ \\
\hline
\end{tabular}


Table 4: Articles classified by methodology

\begin{tabular}{|c|c|c|c|c|c|c|c|}
\hline & טే & 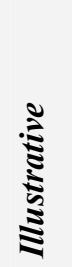 & 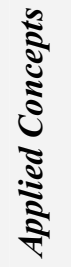 & है & 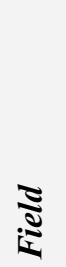 & 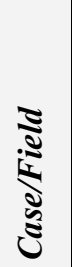 & 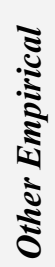 \\
\hline Ågerfalk \& Fitzgerald (2008) & & & & & & $*$ & \\
\hline Ang \& Inkpen (2008) & & & $*$ & & & & \\
\hline Avison \& Banks (2008) & & & & & & & $*$ \\
\hline Bappa et al. (2010) & & & $*$ & & & & \\
\hline Batra (2009) & & $*$ & & & & & \\
\hline Bharadwaj \& Saxena (2009) & & & & & $*$ & & \\
\hline Bharadwaj, Saxena \& Halemane (2010) & & & & & $*$ & & \\
\hline Carmel \& Abbott (2007) & & $*$ & & & & & \\
\hline Cha et al. (2008) & & & $*$ & & & & \\
\hline Chua \& Pan (2008) & & & & $*$ & & & \\
\hline Conchúir et al. (2009) & & & & $*$ & & & \\
\hline D’Mello \& Eriksen (2010) & & & & $*$ & & & \\
\hline D’Mello \& Sahay (2007) & & & & $*$ & & & \\
\hline Dibbern et al. (2008) & & & & $*$ & & & \\
\hline Dutta y Roy (2005) & $*$ & & & & & & \\
\hline Gao, Gopal \& Agarwal (2010) & & & & & & & $*$ \\
\hline Gefen \& Carmel (2008) & & & & & & & $*$ \\
\hline Gonzalez, Gasco \& Llopis (2006b) & & $*$ & & & & & \\
\hline Gonzalez, Gasco \& Llopis (2010) & & & & & $*$ & & \\
\hline Gopal \& Koka (2010) & & & & & $*$ & & \\
\hline Gopal \& Sivaramakrishnan (2008) & & & & & $*$ & & \\
\hline Gopal et al. (2002) & & & & & $*$ & & \\
\hline Gopal et al. (2003) & & & & & $*$ & & \\
\hline Gupta (2009) & & $*$ & & & & & \\
\hline Gupta, Crk \& Bondade (2010) & & $*$ & & & & & \\
\hline Hahn et al (2009) & & & & & & & $*$ \\
\hline Herat \& Kishore (2009) & & & & & & & $*$ \\
\hline Hirschheim (2009) & & $*$ & & & & & \\
\hline Hirschheim \& Newman (2010) & & $*$ & & & & & \\
\hline Iacovou \& Nakatsu (2008) & & & & & & & $*$ \\
\hline Jarvenpaa \& Mao (2008) & & & & $*$ & & & \\
\hline Joshi \& Mudigonda (2008) & & & $*$ & & & & \\
\hline Keil et al (2007) & & & & & & & $*$ \\
\hline Kelly \& Noonan (2008) & & & & $*$ & & & \\
\hline King (2007) & & $*$ & & & & & \\
\hline King (2008) & & $*$ & & & & & \\
\hline Kliem (2004) & & $*$ & & & & & \\
\hline Koong, Liu \& Wang (2007) & & & $*$ & & & & \\
\hline Kotlarsky \& Oshri (2008) & & $*$ & & & & & \\
\hline Kotlarsky et al (2007) & & & & $*$ & & & \\
\hline Krishna et al. (2004) & & $*$ & & & & & \\
\hline Lacity,et al. (2008) & & & & $*$ & & & \\
\hline Lee, G. et al (2006) & & & & $*$ & & & \\
\hline Lee, O-K. et al (2006) & & & & $*$ & & & \\
\hline Leonardi \& Bailey (2008) & & & & & & $*$ & \\
\hline Levina \& Su (2008) & & & & $*$ & & & \\
\hline Levina \& Vaast (2008) & & & & $*$ & & & \\
\hline Mahnke et al. (2008) & & & & $*$ & & & \\
\hline Mao et al. (2008) & & & & & $*$ & & \\
\hline
\end{tabular}




\begin{tabular}{|c|c|c|c|c|c|c|c|}
\hline Metiu (2006) & & & & $*$ & & & \\
\hline Mirani (2007) & & & & $*$ & & & \\
\hline Nair \& Prasad (2004) & & & & & $*$ & & \\
\hline Nakatsu \& Iacovou (2009) & & & & & & & $*$ \\
\hline Nicholson \& Sahay (2001) & & & & $*$ & & & \\
\hline Nicholson \& Sahay (2004) & & & & $*$ & & & \\
\hline Nidumolu \& Goodman (1993) & & $*$ & & & & & \\
\hline Olsson et al. (2008) & & & & $*$ & & & \\
\hline Oshri et al. (2008) & & & & $*$ & & & \\
\hline Palvia et al. (2010) & & & & & $*$ & & \\
\hline Panko (2008) & & $*$ & & & & & \\
\hline Pfannenstein et al. (2004) & & $*$ & & & & & \\
\hline Qu \& Brocklehurst (2003) & & & $*$ & & & & \\
\hline Rai et al. (2009) & & & & & $*$ & & \\
\hline Rajkumar \& Mani (2001) & & $*$ & & & & & \\
\hline Ramarapu et al. (1997) & & $*$ & & & & & \\
\hline Ramasubbu et al. (2008) & & & & & $*$ & & \\
\hline Ramesh et al. (2006) & & & & $*$ & & & \\
\hline Rao (2004) & & $*$ & & & & & \\
\hline Ravichandran \& Ahmed (1993) & & $*$ & & & & & \\
\hline Rottman (2008) & & & & $*$ & & & \\
\hline Rottman \& Lacity (2006) & & & & & $*$ & & \\
\hline Rottman \& Lacity (2008) & & & & $*$ & & & \\
\hline Sabherwal (1999) & & & & $*$ & & & \\
\hline Sakthivel (2007) & & $*$ & & & & & \\
\hline Sarker, Sarker \& Jana (2010) & & & & & $*$ & & \\
\hline Sayeed (2008) & & & & & & & $*$ \\
\hline Seshagiri (1999) & & $*$ & & & & & \\
\hline Shao \& David (2007) & & $*$ & & & & & \\
\hline Simon et al. (2009) & & & & $*$ & & & \\
\hline Sledgianowski, Tafti \& Kierstead (2008) & & & & $*$ & & & \\
\hline Smith et al. (1996) & & & $*$ & & & & \\
\hline Tafti (2005) & & $*$ & & & & & \\
\hline Tambe \& Hitt (2010) & & & & & $*$ & & \\
\hline Tanriverdi et al. (2007) & & & & & $*$ & & \\
\hline Vlaar et al. (2008) & & & & $*$ & & & \\
\hline Wester \& Strahringer (2010) & & & & & $*$ & & \\
\hline Whitaker, Mithas \& Krishnan (2010) & & & & & & & $*$ \\
\hline Winkler et al. (2008) & & & & $*$ & & & \\
\hline Zatolyuk \& Allgood (2004) & & $*$ & & & & & \\
\hline & $\frac{0}{5}$ & 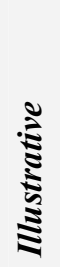 & 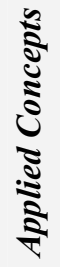 & है & 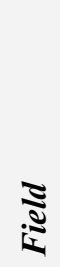 & 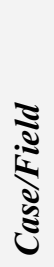 & 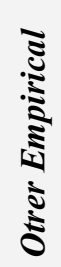 \\
\hline
\end{tabular}


Table 5: Topics in IS Offshore Outsourcing

\begin{tabular}{|l|r|r|r|r|}
\hline & Until $2000(\%)$ & $2001-2005(\%)$ & $2006-2010(\%)$ & TOTAL (\%) \\
\cline { 2 - 4 } Success Factors & $4 ; 3.1$ & $4 ; 3.1$ & $17 ; 13.4$ & $25 ; 19.7$ \\
Risk Factors & $3 ; 2.3$ & $2 ; 1.5$ & $12 ; 9.4$ & $17 ; 13.3$ \\
Knowledge Management & $0 ; 0.0$ & $1 ; 0.7$ & $13 ; 10.2$ & $14 ; 11.0$ \\
Vendor-Client Relationship & $0 ; 0.0$ & $0 ; 0.0$ & $14 ; 11.0$ & $14 ; 11.0$ \\
Project Management & $0 ; 0.0$ & $2 ; 1.5$ & $10 ; 8.6$ & $12 ; 9.4$ \\
Impact on Staff & $0 ; 0.0$ & $1 ; 0.7$ & $9 ; 7.0$ & $10 ; 7.9$ \\
Intercultural Issues & $0 ; 0.0$ & $2 ; 1.5$ & $7 ; 5.5$ & $9 ; 7.0$ \\
OffshoreTypology & $0 ; 0.0$ & $0 ; 0.0$ & $9 ; 7.0$ & $9 ; 7.0$ \\
Geographical Location & $2 ; 1.5$ & $4 ; 3.1$ & $2 ; 1.5$ & $8 ; 6.3$ \\
Decision-making & $2 ; 1.5$ & $0 ; 0.0$ & $2 ; 1.5$ & $4 ; 3.1$ \\
Economic value & $0 ; 0.0$ & $0 ; 0.0$ & $2 ; 1.5$ & $2 ; 1.5$ \\
24h. Knowledge Factory & $0 ; 0.0$ & $0 ; 0.0$ & $2 ; 1.5$ & $2 ; 1.5$ \\
'World-is-flat' proposition & $0 ; 0.0$ & $0 ; 0.0$ & $1 ; 0.7$ & $1 ; 0.7$ \\
\hline TOTAL & $11 ; 8.7$ & $16 ; 12.6$ & $100 ; 78.7$ & $127 ; 100.0$ \\
\hline
\end{tabular}


Table 6: Articles classified by topic

\begin{tabular}{|c|c|c|c|c|c|c|c|c|c|c|c|c|c|}
\hline & 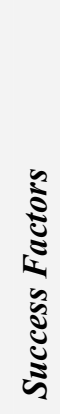 & 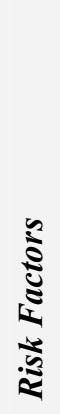 & 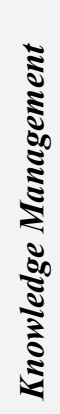 & 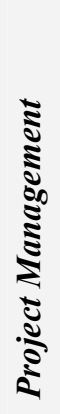 & 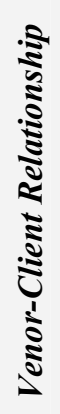 & 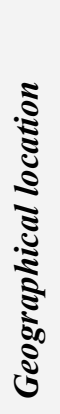 & 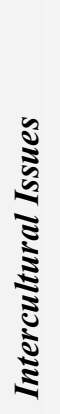 & 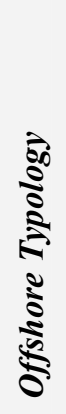 & $\begin{array}{l}5 \\
5 \\
5 \\
5 \\
5 \\
\vdots \\
\vdots \\
\vdots \\
5\end{array}$ & 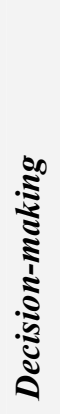 & 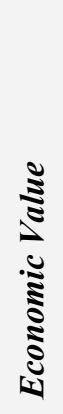 & 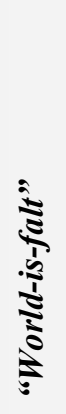 & 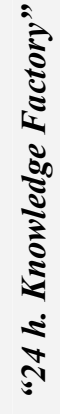 \\
\hline Ågerfalk \& Fitzgerald (2008) & $*$ & & & $*$ & & & & $*$ & & & & & \\
\hline Ang \& Inkpen (2008) & $*$ & & & & & & $*$ & & & & & & \\
\hline Avison \& Banks (2008) & & & & & & & $*$ & & & & & & \\
\hline Bapna, Barua \& Mehra (2010) & & & & & & & & $*$ & & & & & \\
\hline Batra (2009) & & $*$ & & & & & & & & & & & \\
\hline Bharadwaj \& Saxena (2009) & $*$ & & & & $*$ & & & & & & & & \\
\hline Bharadwaj, Saxena \& Halemane (2010) & $*$ & & & & $*$ & & & & & & & & \\
\hline Carmel \& Abbott (2007) & & & & & & & & $*$ & & & & & \\
\hline Cha et al. (2008) & & & $*$ & & & & & & & & $*$ & & \\
\hline Chua \& Pan (2008) & & & $*$ & & & & & & & & & & \\
\hline Conchúir et al. (2009) & & $*$ & & & & & & & & & & & \\
\hline D’Mello \& Eriksen (2010) & & & & & & & $*$ & & $*$ & & & & \\
\hline D’Mello \& Sahay (2007) & & & & & & & & & $*$ & & & & \\
\hline Dibbern et al. (2008) & & & & & & & $*$ & & & & & & \\
\hline Dutta \& Roy (2005) & $*$ & & & & & & & & & & & & \\
\hline Gao, Gopal \& Agarwal (2010) & $*$ & & & & $*$ & & & & & & & & \\
\hline \multicolumn{14}{|l|}{ Gefen \& Carmel (2008) } \\
\hline Gonzalez, Gasco \& Llopis (2006b) & $*$ & $*$ & & & & & & $*$ & & & & & \\
\hline Gonzalez, Gasco \& Llopis (2010) & $*$ & $*$ & & & & & & & & & & & \\
\hline Gopal \& Koka (2010) & & & & $*$ & & & & & & & & & \\
\hline Gopal \& Sivaramakrishnan (2008) & & & & $*$ & & & & & & & & & \\
\hline Gopal et al. (2002) & $*$ & & & & & & & & & & & & \\
\hline Gopal et al. (2003) & & & & $*$ & & & & & & & & & \\
\hline \multicolumn{14}{|l|}{ Gupta (2009) } \\
\hline Gupta, Crk \& Bondade (2010) & & & $*$ & & & & & & & & & & $*$ \\
\hline Hahn et al (2009) & & $*$ & & & & & & & & & & & \\
\hline Herat \& Kishore (2009) & & $*$ & & & & & & & & & & & \\
\hline Hirschheim (2009) & & & & & & & & & $*$ & & & & \\
\hline Hirschheim \& Newman (2010) & & & & & & & & & $*$ & & & & \\
\hline Iacovou \& Nakatsu (2008) & & $*$ & & & & & & & & & & & \\
\hline Jarvenpaa \& Mao (2008) & & & $*$ & & & & & $*$ & & & & & \\
\hline Joshi \& Mudigonda (2008) & & & & & & $*$ & & & & & & & \\
\hline Keil et al (2007) & & $*$ & & & & & $*$ & & & & & & \\
\hline Kelly \& Noonan (2008) & $*$ & & & & $*$ & & & & & & & & \\
\hline King (2007) & $*$ & & & $*$ & & & & & & & & & \\
\hline King (2008) & $*$ & & & $*$ & & & & & & & & & \\
\hline Kliem (2004) & & $*$ & & & & & & & & & & & \\
\hline Koong, Liu \& Wang (2007) & & & & & & & & & & $*$ & & & \\
\hline Kotlarsky \& Oshri (2008) & & & & & & $*$ & & & & & & & \\
\hline Kotlarsky et al (2007) & & & $*$ & & & & & & & & & & \\
\hline Krishna et al. (2004) & & & & $*$ & & & $*$ & & & & & & \\
\hline Lacity,et al. (2008) & & & & & & & & & $*$ & & & & \\
\hline Lee, G. et al (2006) & & & & $*$ & & & & & & & & & \\
\hline Lee, O-K. et al (2006) & & & & $*$ & & & & & & & & & \\
\hline Leonardi \& Bailey (2008) & & & $*$ & & & & & & & & & & \\
\hline
\end{tabular}




\begin{tabular}{|c|c|c|c|c|c|c|c|c|c|c|c|c|c|}
\hline Levina \& Su (2008) & & & & & & & & * & & & & & \\
\hline Levina \& Vaast (2008) & & & & & * & & & & & & & & \\
\hline Mahnke et al. (2008) & & & & & $*$ & & & $*$ & & & & & \\
\hline Mao et al. (2008) & & & & & $*$ & & & & & & & & \\
\hline Metiu (2006) & & & & & * & & & & & & & & \\
\hline Mirani (2007) & & & & & $*$ & & & & & & & & \\
\hline Nair \& Prasad (2004) & & & & & & $*$ & & & & & & & \\
\hline Nakatsu \& Iacovou (2009) & & * & & & & & & & & & & & \\
\hline Nicholson \& Sahay (2001) & & & & & & & $*$ & & & & & & \\
\hline Nicholson \& Sahay (2004) & & & * & & & & & & & & & & \\
\hline Nidumolu \& Goodman (1993) & & & & & & * & & & & & & & \\
\hline Olsson et al. (2008) & & & & & $*$ & & & $*$ & & & & & \\
\hline Oshri et al. (2008) & & & * & & & & & & & & & & \\
\hline Palvia et al. (2010) & & & & * & * & & & & & & & & \\
\hline Panko (2008) & & & & & & & & & $*$ & & & & \\
\hline Pfannenstein et al. (2004) & & * & & & & & & & $*$ & & & & \\
\hline Qu \& Brocklehurst (2003) & & & & & & * & & & & & & & \\
\hline Rai et al. (2009) & $*$ & & & & * & & $*$ & & & & & & \\
\hline Rajkumar \& Mani (2001) & * & & & & & $*$ & & & & & & & \\
\hline Ramarapu et al. (1997) & * & $*$ & & & & & & & & $*$ & & & \\
\hline Ramasubbu et al. (2008) & & & * & & & & & & & & & & \\
\hline Ramesh et al. (2006) & * & & * & & & & & & & & & & \\
\hline Rao (2004) & * & & & & & & & & & & & & \\
\hline Ravichandran \& Ahmed (1993) & $*$ & * & & & & & & & & $*$ & & & \\
\hline Rottman (2008) & * & & * & & & & & & & & & & \\
\hline Rottman \& Lacity (2006) & * & & & & & & & & & & & & \\
\hline Rottman \& Lacity (2008) & $*$ & & & & & & & & & & & & \\
\hline Sabherwal (1999) & $*$ & & & & & & & & & & & & \\
\hline Sakthivel (2007) & & $*$ & & & & & & & & & & & \\
\hline Sarker, Sarker \& Jana (2010) & & & & & & & & & $*$ & & & & \\
\hline Sayeed (2008) & & * & & & $*$ & & & & & $*$ & & & \\
\hline Seshagiri (1999) & & & & & & $*$ & & & & & & & \\
\hline Shao \& David (2007) & & & & & & & & & * & & & & \\
\hline Simon et al. (2009) & & & & & $*$ & & & & & & & & \\
\hline Sledgianowski, Tafti \& Kierstead (2008) & & & & & & & & $*$ & & & & & \\
\hline Smith et al. (1996) & * & $*$ & & & & & & & & & & & \\
\hline Tafti (2005) & & * & & & & & & & & & & & \\
\hline Tambe \& Hitt (2010) & & & & & & & & & $*$ & & & & \\
\hline Tanriverdi et al. (2007) & & & & $*$ & & & & & & & & & \\
\hline Vlaar et al. (2008) & & & $*$ & $*$ & & & & & & & & & \\
\hline Westner \& Strahringer (2010) & $*$ & & & & & & & & & & & & \\
\hline Whitaker, Mithas \& Krishnan (2010) & & & * & & & & & & & & & & \\
\hline Winkler et al. (2008) & $*$ & & & & & & $*$ & & & & & & \\
\hline Zatolyuk \& Allgood (2004) & & & & & & $*$ & & & & & & & \\
\hline & 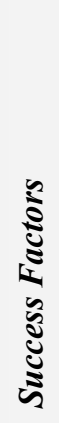 & 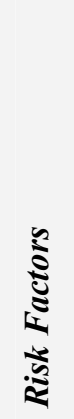 & 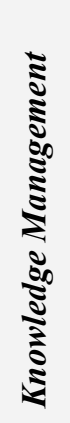 & 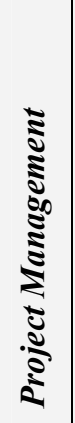 & 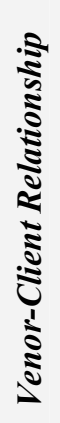 & 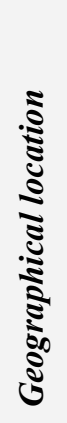 & 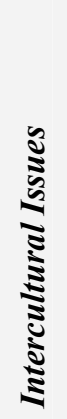 & 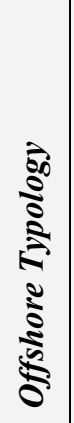 & 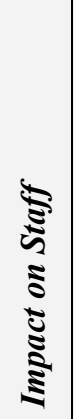 & 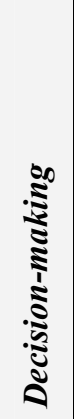 & 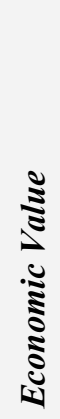 & 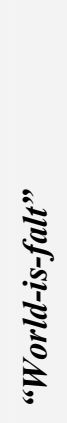 & 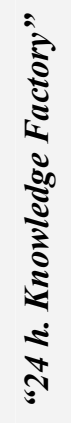 \\
\hline
\end{tabular}


Table 7: Authors with the most articles on IS Offshore Outsourcing

\begin{tabular}{|llllll|}
\hline \multicolumn{1}{|c|}{ Author } & N & \multicolumn{1}{c|}{ Country } & \multicolumn{1}{c|}{ Author } & N & \multicolumn{1}{c|}{ Country } \\
\hline Gopal, A. & 5 & USA & Hillegersberg, & 2 & The Netherlands \\
Krishnan, M.S. & 4 & USA & Hirscheim, R. & 2 & USA \\
Sahay, S. & 4 & Norway & Holmström Olsson, H. & 2 & Sweeden \\
Agerfalk, P.J. & 3 & Sweden & Iacovou, Ch. L. & 2 & USA \\
Fitzgerald, B. & 3 & Ireland & King, W.R. & 2 & USA \\
Kotlarsky, J. & 3 & United Kingdom & Kumar, K. & 2 USA \\
Lacity, M.C. & 3 & USA & Levina, N. & 2 USA \\
Oshri, I. & 3 & The Netherlands & Llopis, J. & 2 Spain \\
Rottman, J.W. & 3 & USA & Mao, J-Y. & 2 China \\
Bharadwaj, S.S. & 2 & India & Mithas, S. & 2 USA \\
Carmel, E. & 2 & USA & Mukhopadhyay, T. & 2 USA \\
Conchúir, E.O. & 2 & Suiza & Nakatsu, R.T. & 2 USA \\
Dibbern, J. & 2 & Germany & Nicholson, B. & 2 United Kingdom \\
D’Mello, M. & 2 & (Norway/India) & Saxena, K.B.C. & 2 & India \\
Gasco, J. & 2 & Spain & Sivaramakrishna & 2 & USA \\
Gonzalez, R. & 2 & Spain & Tafti, M.H.A. & 2 & USA \\
Gupta, A. & 2 & USA & Van Fenema, P. & 2 & The Netherlands \\
Heinzl, A. & 2 & Germany & Winkler, J. & 2 Germany \\
\hline
\end{tabular}

Table 8: Countries which contribute the most to IS Offshore Outsourcing research

\begin{tabular}{|lr|}
\hline \multicolumn{1}{|c}{ Country } & $\mathrm{N}$ \\
\hline USA & 116 \\
India & 15 \\
The Netherlands, United Kingdom & 11 \\
Spain & 9 \\
Germany, Ireland & 8 \\
China, Norway & 7 \\
Sweden & 6 \\
Singapore & 4 \\
Denmark & 3 \\
France & 2 \\
Canada, Korea & 1 \\
\hline
\end{tabular}


Figure 1: The Analysis Roadmap

Analyze the article to determine...

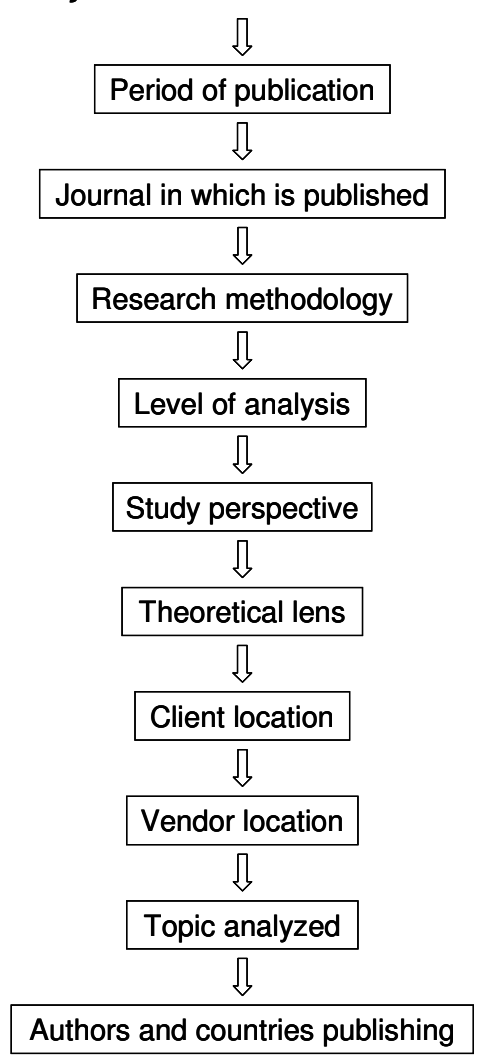

Figure 2: Number of IS Offshore Outsourcing articles analysed

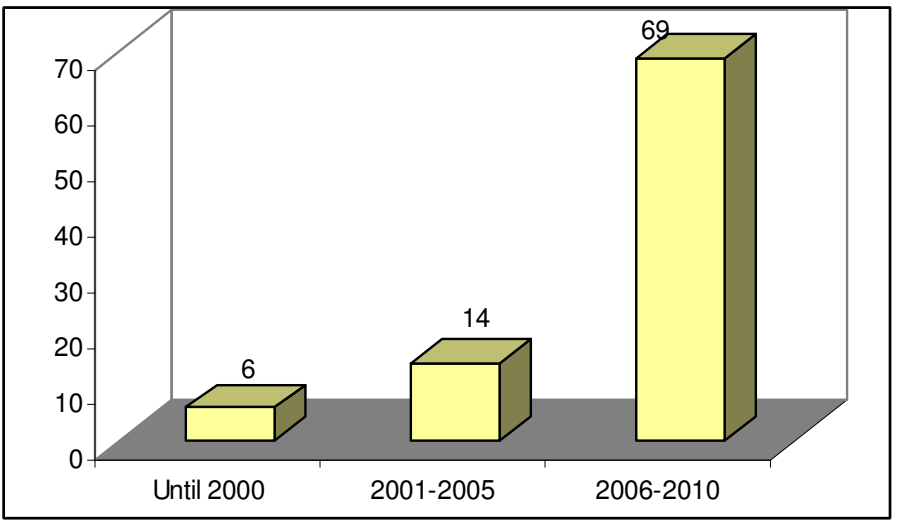


Figure 3: Level of analysis

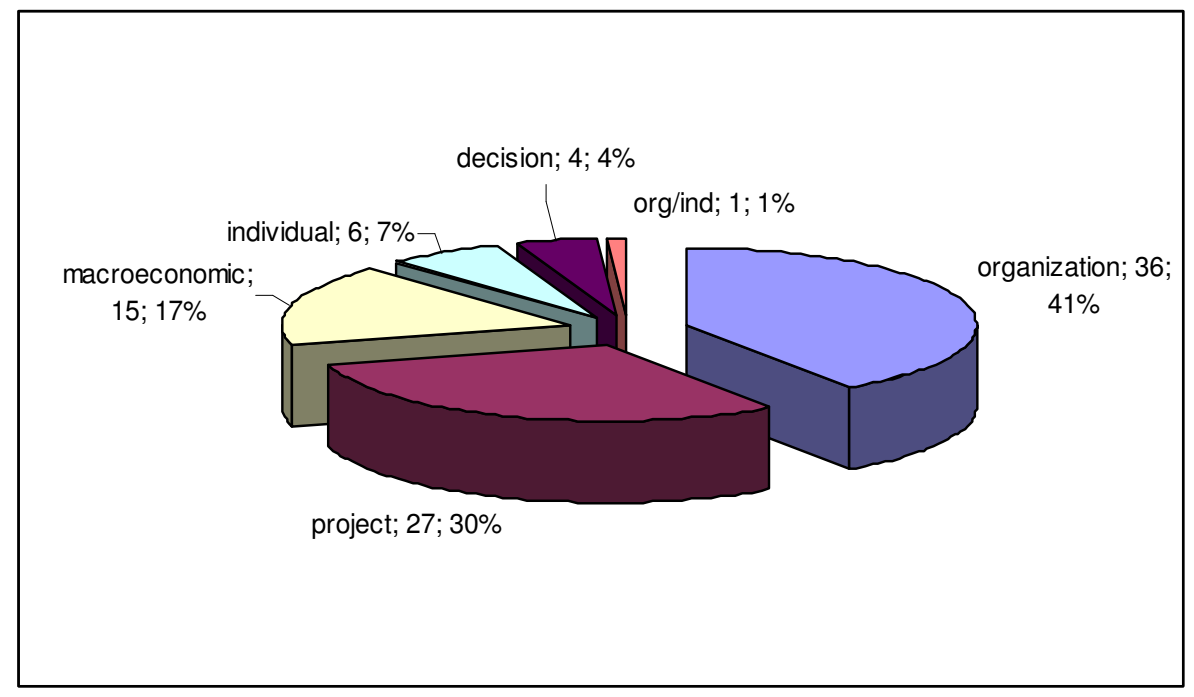

Figure 4: The data perspective

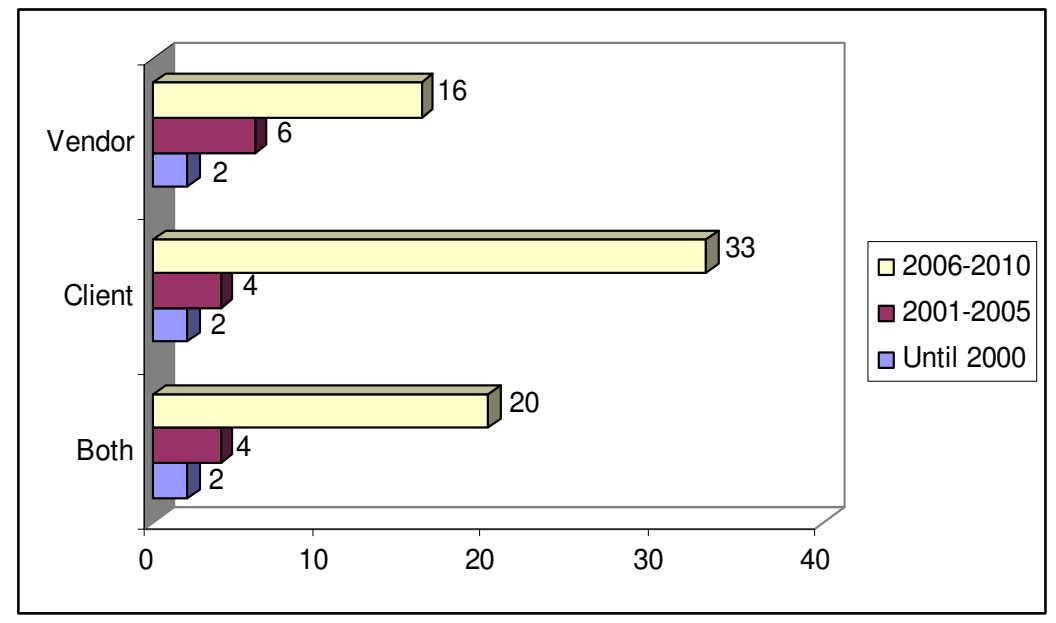


Figure 5: Theoretical lens

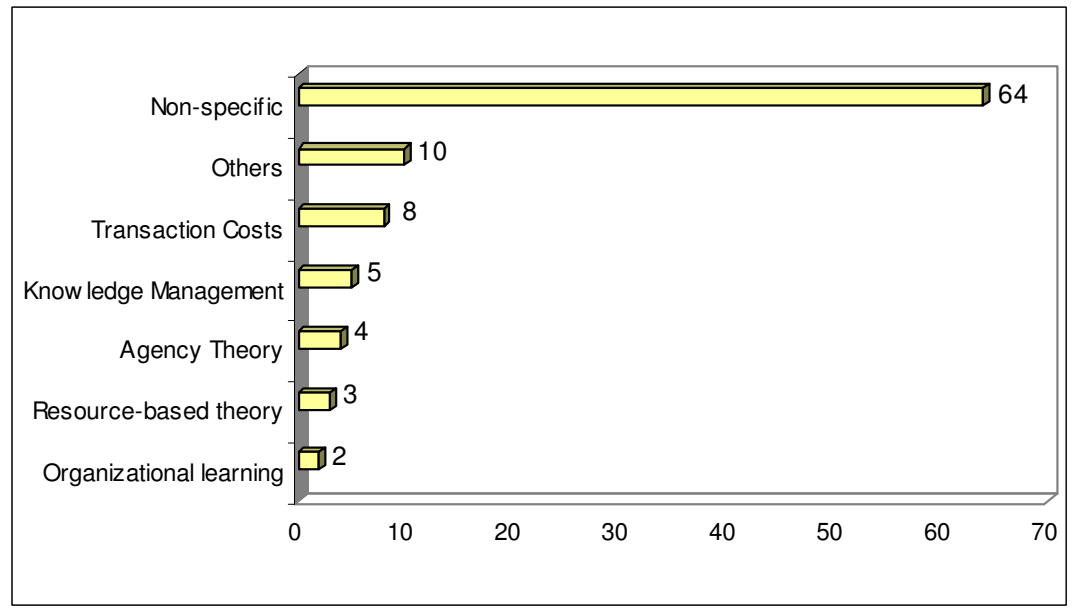

Figure 6: Client Location

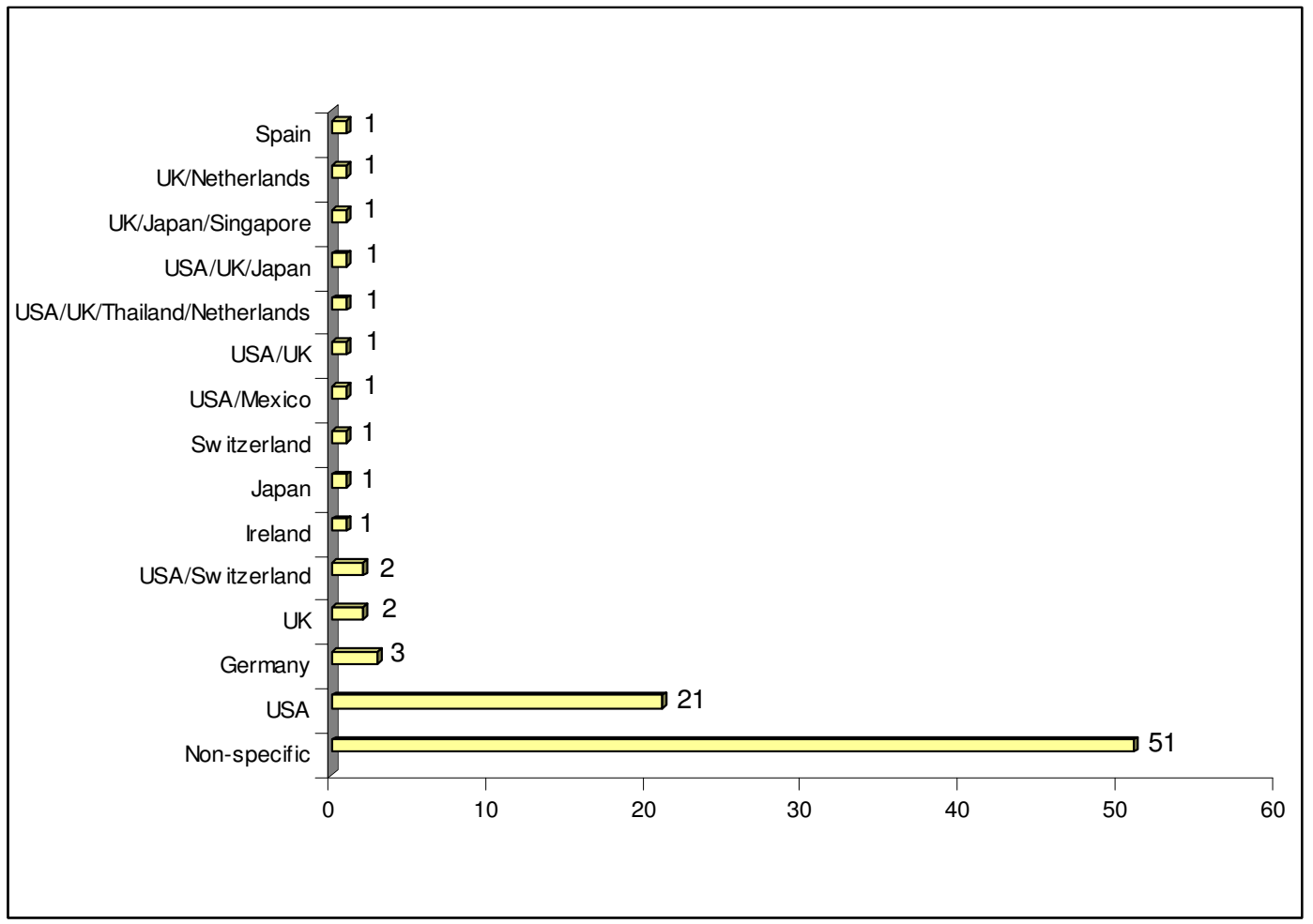


Figure 7: Vendor Location

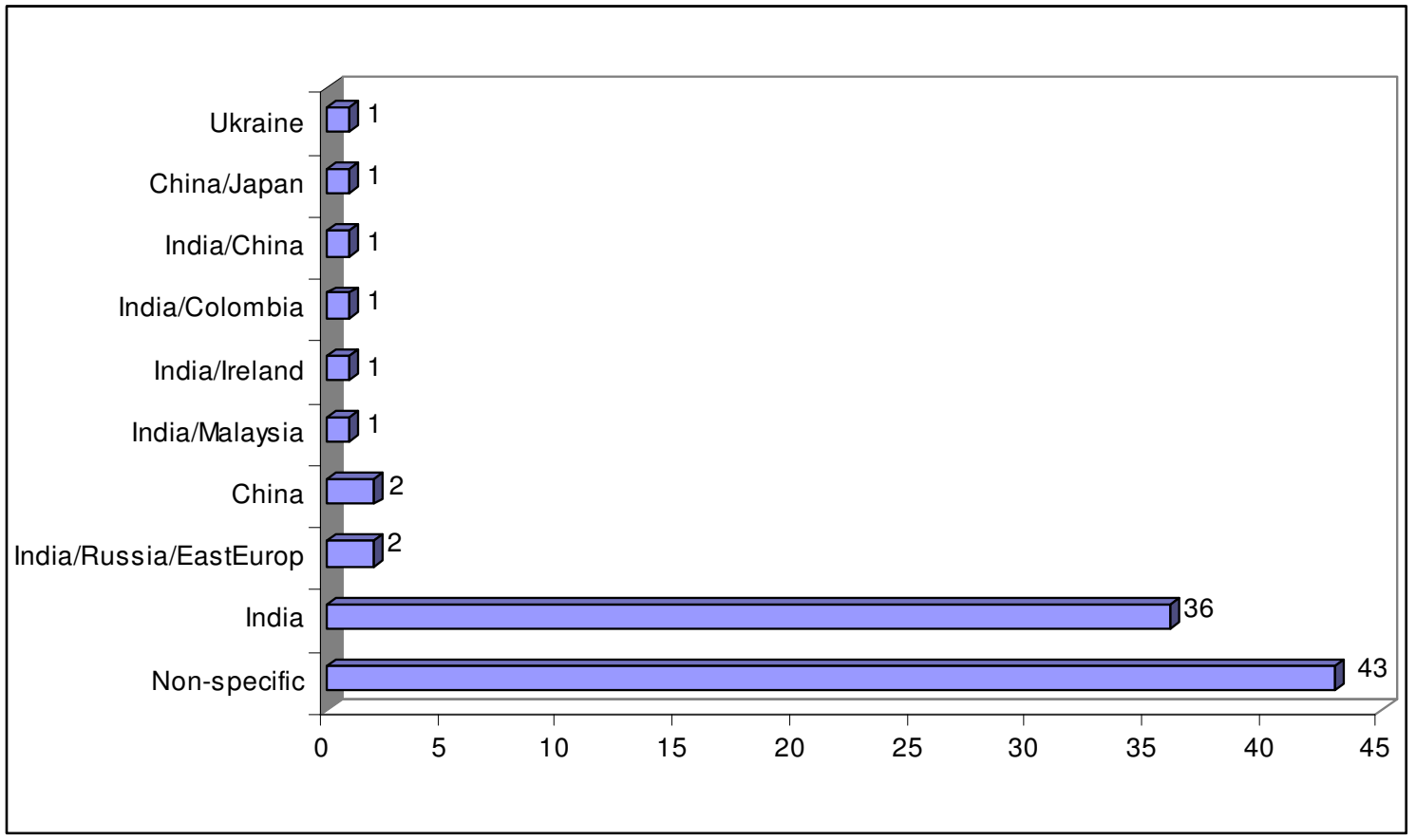

